\title{
Alll06 260640
}

NBSIR $85-2998$

\section{Effect of Wall and Room}

Surfaces on the Rates of Heat, Smoke, and Carbon Monoxide Production in A Park Lodging Bedroom Fire

3. T. LeE

L'S DEPARTMENT OF CUMMEACE

Nationa! Bureau cf Siandards

Narional Engineering Laboratory

Center foi Fire Research.

Sarthersburg, no 20893

February 1985

QC

100

, 456

$35-2998$

1985 



\section{EFFECT OF WALL AND ROOM} SURFACES ON THE RATES OF HEAT, SMOKE, AND CARBON MONOXIDE PRODUCTION IN A PARK LODGING BEDROOM FIRE

B. T. Lee

U.S. DEPARTMENT OF COMMERCE

National Bureau of Standards

National Engineering Laboratory

Center for Fire Research

Gaithersburg, MD 20899

February 1985

Sponsored in part by:

U.S. Park Service

U.S. Department of the Interior

Washington, DC

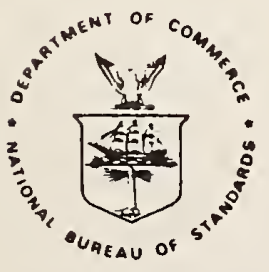

U.S. DEPARTMENT OF COMMERCE, Malcolm Baldrige, Secretary NATIONAL BUREAU OF STANDARDS. Ernest Ambler. Director 

$\underline{\text { Page }}$

LIST OF TABLES $\ldots \ldots \ldots \ldots \ldots \ldots \ldots \ldots \ldots \ldots \ldots \ldots \ldots \ldots \ldots \ldots \ldots \ldots \ldots \ldots$

LIST OF FIGURES $\ldots \ldots \ldots \ldots \ldots \ldots \ldots \ldots \ldots \ldots \ldots \ldots \ldots \ldots \ldots \ldots \ldots \ldots \ldots \ldots \ldots$

Abstract $\ldots \ldots \ldots \ldots \ldots \ldots \ldots \ldots \ldots \ldots \ldots \ldots \ldots \ldots \ldots \ldots \ldots \ldots \ldots \ldots \ldots \ldots \ldots \ldots \ldots$

1. INTRODUCTION $\ldots \ldots \ldots \ldots \ldots \ldots \ldots \ldots \ldots \ldots \ldots \ldots \ldots \ldots \ldots \ldots \ldots \ldots \ldots \ldots \ldots \ldots \ldots . \ldots . \ldots \ldots$

2. EXPERIMENTAL .................................... 4

2.1 Bedroom Furnishing Fire Tests ...................... 4

2.2 Fire Load and Ignition Source $\ldots \ldots \ldots \ldots \ldots \ldots \ldots \ldots \ldots \ldots \ldots \ldots$

2.3 Instrumentation $\ldots \ldots \ldots \ldots \ldots \ldots \ldots \ldots \ldots \ldots \ldots \ldots \ldots \ldots \ldots \ldots \ldots \ldots . \ldots \ldots \ldots$

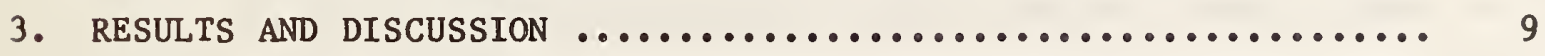

3.1 Open Burn Fires ................................ 9

3.2 Room Burn Fires ................................ 11

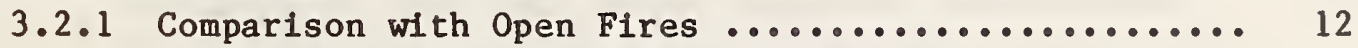

3.2.2 Sprinkler Response and Smoke Detection ........... 14

3.2.3 Effect of Door Closure on Fire ................ 16

3.2.4 Mass Flow Calculations ....................... 16

4. SUMMARY AND CONCLUSIONS ........................... 18

5. ACKNOWLEDGMENTS .................................. 20

6. REFERENCES ........................................ 20

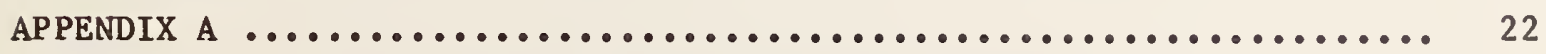

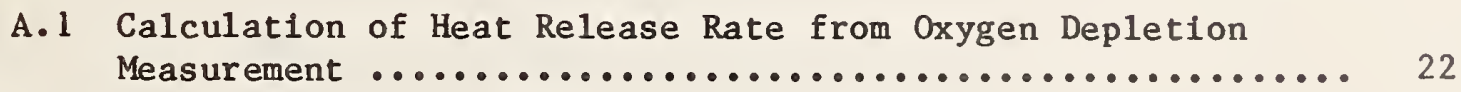

A. 2 Quantification of Smoke from Room Fire Tests .......... 23 
Table 1. Room Fire Tests ............................ 25

Table 2. Open Burn Tests ............................ 26

Table 3. Fuel Loading in Fire Tests ,.................... 27

Table 4. Wastebasket Ignition Source $\ldots \ldots \ldots \ldots \ldots \ldots \ldots \ldots \ldots \ldots$

Table 5. Location of Instrumentation ...................... 29

Table 6. Sprinkler Response Times ......................... 30

Table 7. Activation Times for Smoke Detectors in Test R6 ....... 31

Table 8. Heat Release and Heat Output Measurements ............ 32

Table 9. Carbon Monoxide, Thermal Flux, and Smoke Measurements ... 33

Table 10. Flashover Times and Peak Air Temperatures in Room

Fire Tests ......................................... 34

Table 11. Carbon Monoxide Measurements for Test R6 ........... 35 


\section{LIST OF FIGURES}

\section{Page}

Figure 1. Test Room Exhaust Hood Arrangement and Instrumentation .... 36

Figure 2. Furnishing Arrangement with Wastebasket Ignition Source ... 37

Figure 3. Plan View of Fire Test Room Arrangement ............. 38

Figure 4. Heat Release Rates for Open Burns of Furnishing Fires with No Wall ................................... 39

Figure 5. Heat Release Rates for Open Burns of Furnishing Fires Adjacent Gypsum Board Wall ...................... 40

Figure 6. Heat Release Rates for Open Burns of Furnishing Fires

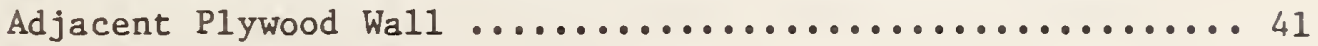

Figure 7. Comparison of Heat Release Rates for All Six Open Burns ... 42

Figure 8. Heat Release Rates for Room Furnishing Fires with Plywood Walls ................................ 43

Figure 9. Heat Release Rates for Room Furnishing Fires with Gypsum Board Walls ............................ 44

Figure 10. Heat Outflow Rates from Room Furnishing Fires with

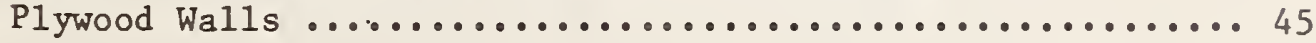

Figure 11. Heat Outflow Rates from Room Furnishing Fires with Gypsum Board Walls .......................... 46

Figure 12. Comparison of Mass Flow Calculations for Test Rl ....... 47

Figure 13. Comparison of Mass Flow Calculations for Test R2 ....... 48

Figure 14. Comparison of Mass Flow Calculations for Test R4 ....... 49

Figure 15. Comparison of Mass Flow Calculations for Test R5 ....... 50 

EFFECT OF WALL AND ROOM SURFACES ON THE RATES OF HEAT, SMOKE, AND CARBON MONOXIDE PRODUCTION IN A PARK LODGING BEDROOM FIRE

B. T. Lee

Abstract

A furnishing arrangement representative of those in U.S. Park Service lodging facilities was evaluated for its open burn (free burn) characteristics. The arrangement consisted of a double bed with a wood headboard and one wood night table. The proximity of a wall and the effect of a room on the combustion of the same arrangement were examined. Wa1l finish materials were gypsum board and plywood. The presence or combustibility of an adjacent wall did not have a significant effect on the burning behavior of the furnishing arrangement. Nor did the effect of a room enclosure for the first few minutes subsequent to ignition. However, after this initial time interval, the effect of a room, lined with gypsum board finish, on the burning furnishings was pronounced, with flashover occurring as early as $233 \mathrm{~s}$ with heat release rates of over $2 \mathrm{MW}$. This compared with a peak rate of $1.2 \mathrm{MW}$ for the open burn. Wood paneling in the room increased the peak rate to $7 \mathrm{MW}$. Mass flow of hot gases, smoke, and carbon monoxide from the room fires were measured. The use of a sprinkler or automatic door closing device activated by a smoke detector was shown to prevent room flashover.

Key words: beds (furniture); carbon monoxide; fire growth; flashover; fuel 1oad; furniture: heat release rate; interior finishes; room fires; smoke: smoke detectors; sprinkler systems; 


\section{INTRODUCTION}

Combustible furnishings along whth the extensive use of wood and wood product materials throughout U.S. Park Service (USPS) facilities could pose a fire hazard in the majority of their buildings. Fire in a building, other than that resulting from arson, is intrinsically an accidental occurrence, and the initiation and spread of fire in a room can occur in a great variety of ways. However, to fire test every possible fire scenario becomes impractical in terms of cost and time. A relatively simple analytical model [1] ${ }^{1}$ which predicts the dynamic fire conditions and available time for safe egress in rooms of fire origin was developed to help assess the fire hazard in such facilities. The model predictions were based on the assumption that the onset of hazardous conditions within the room w111 occur at temperature and combustion product concentration levels which are low compared to those levels at which variations from open burn (free burn) will begin to be significant. Required inputs to the model included the open burn characteristics of the fuel assembly, 1.e., the furnishings and interior finish. (Open burn is defined as a burn of the fuel assembly in a large ventilated space which contains a relatively quiescent atmosphere).

Besides the concern for onset of hazard in a room of fire involvement is the concern of flashover potential. Room flashover greatly increases the hazard to adjoining spaces. Production of heat and combustion products at this point becomes a serious threat to the rest of the building. Theoretically, and to engineering accuracy, it may be possible to predict the flash-

$\overline{1_{\text {Numbers }} \text { in brackets }}$ refer to the literature references listed at the end of this report. 
over potential of a room using free burn characteristics of the fire load in the room. In practice, this is difficult and has not yet been attempted. One reason being that, prior to the present test program, sufficient comparable free burn/room burn test data have not been acquired. An understanding of fire growth phenomena and of analytical calculational techniques, e.g., those for computing mass flow out of the room, are prerequisite for success in this area. Such understanding can be achleved by designing fire tests in a manner as to help develop, refine, and ultimately validate such prediction models. In the process of studying the fire test data, simplifying assumptions which are reasonable to incorporate in mathematical models may become evident. Also, experimental and analytical areas demanding further study may become more obvious.

The present test series was designed in increasingly complex test arrangements so as to help acquire the desired understanding. The tests ranged from open burn room furnishing fires to room fires involving identical furnishings. Thus, the objectives of this study are:

1. to evaluate the open burn characteristics of a typical USPS lodging furnishing arrangement;

2. to determine the effect of a single wall surface, lined with noncombustible or combustible materials, on the fire behavior of the furnishing arrangement; and

3. to ascertain the effect of room surfaces on the same arrangement. 
In addition, the data from the room fire tests are to be used to evaluate the calculational methods for determining mass flow out of the room.

\section{EXPERIMENTAL}

\subsection{Bedroom Furnishing Fire Tests}

Six open fire tests, i.e., unconfined fires in a large open space, and six room fire tests of one bedroom furnishing arrangement were perforned. These tests are outlined in tables 1 and 2. The test room and exhaust hood arrangement is shown in figure 1. As can be seen, the test room was located adjacent to the $3.7 \mathrm{~m} \times 4.9 \mathrm{~m}$ exhaust collector hood which had an exhaust flow capacity of about $3 \mathrm{~m}^{3} / \mathrm{s}$. In the open burns, the furnishing arrangement was located direct $1 \mathrm{y}$ under the hood with the headboard positioned $0.76 \mathrm{~m}$ away from the exterior front wall of the room. Two of the open burns had a $2.44 \times 2.44 \mathrm{~m}$ free standing wal1 $25.4 \mathrm{~mm}$ behind the headboard and in front of the room. This wall was constructed from 12.7 mm gypsum board mounted on $51 \mathrm{~mm} \times 102 \mathrm{~mm}$ steel studs $0.41 \mathrm{~m}$ apart. Two other open burns had $6.4 \mathrm{~mm}$ plywood lining the same free standing wall. For the room tests, the headboard was located $40 \mathrm{~mm}$ away from the back wa11. Interior dimensions of the room were $2.44 \mathrm{~m}$ wide, $3.66 \mathrm{~m}$ deep, and $2.44 \mathrm{~m}$ high. The back and two side walls were $12.7 \mathrm{~mm}$ gypsum board mounted over $51 \mathrm{~mm}$ x $102 \mathrm{~mm}$ steel studs $0.41 \mathrm{~m}$ apart. The celling was fabricated from $15.9 \mathrm{~mm}$ fire resistant gypsum board over a sublayer of $25 \mathrm{~mm}$ thick calcium silicate board and was attached to the underside of several steel joists spanning the side walls. The front wall, with a $0.76 \mathrm{~m}$ wide and $2.03 \mathrm{~m}$ high doorway, was constructed from a single layer of the calcium silicate board. Three of the room tests had $6.4 \mathrm{~mm}$ 
plywood over the gypsum board on the two side walls and the back wall. In one of the gypsum board 1 ined room tests, test $6, a 0.76 \mathrm{~m}$ wide $\mathrm{x} 2.03 \mathrm{~m}$ high and $9.55 \mathrm{~mm}$ thick door made from transparent methylmethacrylate was used for manually closing off the room upon activation of the smoke detector.

\subsection{Fire Load and Ignition Source}

The furnishing arrangement shown in figures 2 and 3 was used for these tests and was based on an inspection of some selected USPS lodging facilities at Yosemite National Park, California, and at Shenandoah National Park, Virginia. The room furnishings consisted of a $1.37 \mathrm{~m}$ wide, $1.91 \mathrm{~m}$ long, and $0.53 \mathrm{~m}$ high double bed, a $2.39 \mathrm{~m}$ wide and $0.89 \mathrm{~m}$ high headboard and a $0.51 \mathrm{~m}$ wide $\times 0.41 \mathrm{~m}$ deep $\times 0.63 \mathrm{~m}$ high night table. Both headboard and night table were fabricated from $12.7 \mathrm{~mm}$ thick plywood. The bedding was comprised of two pillows, two pillow cases, two sheets and one blanket. The pillows had a polypropylene olefin fabric with a polvester fill. The pillow cases and sheets were polyester-cotton. The blanket was acrylic material. The bedding was left in a "slept in" condition which was duplicated to the degree possible in each test. The spring mattress had the same upholstery and parding on the top as on the bottom. The upholstery was a polvester quilted cover. Padding consisted of $6.4 \mathrm{~mm}$ polyurethane over a fire-retarded cotton felt layer with sublayers of a cotton felt and a synthetic cellulosic fiber pad. The box spring had a covering of polyester material over a layer of cotton felt and a sublayer of cellulosic fiber pad. Underneath this padding is a wood frame with a steel wire grid on top and a cellulosic cloth cover on the bottom. The combustible weight of each ttem in the room is given in table 3 . The total

combustible fire load for this arrangement was $6.0 \mathrm{~kg} / \mathrm{m}^{2}$ of floor area. W1th 
three walls of the room lined with $6.4 \mathrm{~mm}$ plywood, the room fire load came to $14.8 \mathrm{~kg} / \mathrm{m}^{2}$ of floor area. This compares with an average fire load of $23 \mathrm{~kg} / \mathrm{m}^{2}$ for a recreational room in a single family home in the Washington, D.C. metropolitan area [2].

In all of the tests, the fire was started with a match flame ignition of a $0.34 \mathrm{~kg}$ plastic (240 $\mathrm{mm} 140 \mathrm{~mm} \times 24 \mathrm{~mm}$ high) wastebasket, filled with $0.41 \mathrm{~kg}$ of trash, positioned adjacent to the night table and against the bed. An earlier study [3] on mattress flammability employed a wastebasket ignition source. Since a wastebasket represents a realistic actual fire ignition source, it was used in this study using the same type of trash contents and stacking of the contents as in that study. The type and distribution of the contents of the wastebasket is shown in table 4.

\subsection{Instrumentation}

Measurements were made in the room and doorway to characterize the fire environment and to allow calculation of the mass flow from the room. These measurements included the vertical air temperature and pressure gradients in the room and air temperature and velocity gradients along the doorway centerline. Total incident heat flux to a horizontal target on the floor was monitored along with the thermal radiance to a vertical surface measured at a height of $0.64 \mathrm{~m}$ in the room, next to the left wa11, facing the wastebasket. In addition, carbon monoxide and carbon dioxide concentrations were recorded at the $0.30 \mathrm{~m}$ and $1.5 \mathrm{~m}$ heights in the room for test $\mathrm{R} 6$. Measurements were also taken in the room to help evaluate sprinkler head and smoke detector responses to the fire environment. Temperatures, velocities, and oxygen and 
carbon dioxide concentrations in the exhaust gases in the stack were monitored to determine the mass flow through the stack and $\dot{Q}_{s}$, the total rate of heat production by the fire. In calculating $\dot{Q}_{S}$, about 13 megajoules is obtained from each kilogram of oxygen consumed in the burning of materials normally used in the construction and furnishing of rooms [4]. Thus, the total rate of heat generation from burning furnishings in a room can be obtained by measuring the oxygen content and volume flow rate of the gases discharged from the fire [5]. Details concerning the calculation of $\dot{\eta}_{s}$ are given in Appendix A. 1 of this report.

An average temperature taken across the inlet of the exhaust collection hood was used together with the mass flow in the stack to estimate $h_{s}$, the total flux of heat from the fire test room ( $\dot{Q}_{S}$ minus the heat loss to the room boundaries). The estimated value for the quantity $h_{s}$ is actually equal to $h_{s}$ minus the heat loss to the surroundings between the room doorway and the inlet of the exhaust collection system. Smoke and carbon monoxide were also monitored in the stack to help quantify these products of combustion from the room fires. The quantification of smoke from room fires is discussed in detail in Appendix A.2.

Location of all instrumentation in these room fires is indicated in table 5 and figure 1. Temperatures in the room and doorway were measured with chromel-alumel thermocouples made with $0.05 \mathrm{~mm}$ wire. These thermocouples were difficult to prepare and were vulnerable to breakage under normal fire test operations. More robust thermocouples fabricated from $0.51 \mathrm{~mm}$ chromel-alumel wires were also employed at these same locations. The larger thermocouples were more susceptible to radiation error [6] and were used primar1ly as backup 
measurements. Pressures in the room were measured with probes mounted in one corner of the burn room, flush with the interior surface of the front wall, along the height of the room. Bidirectional velocity probes [7] were employed for measuring the air velocity in the doorway and to note the occurrence of any flow reversal along the doorway. Heat flux was monitored with watercooled total heat flux gauges of the Gardon type. Crumpled newspaper on the floor was also used to indicate if and when the irradiance was sufficient to ignite such light combustible materials in the lower half of the room. Nondispersive infrared analyzers were used to record the concentrations of carbon monoxide and carbon dioxide in the room and in the stack. Stack velocities were measured with pitot-static probes. Stack temperatures were monitored with chromel-alumel thernocouples fabricated from 0.51 whre. Oxygen concentration was measured with a paramagnetic type instrument. The optical density of the smoke was determined by attenuation of a light beam in the stack. Neutral optical density filters were used to calibrate the light sensor over the range of optical densities from 0.04 to 3.0 . The optical measurements, when calibrated in this manner, provide a useful measure of optical density. However, a more detailed calibration of the optical system with smoke of known concentration would be required for an accurate measurement of optical densities above about 1.5. At the inlet of the hood, the average temperature was monitored with a grid of 25 chrome1-alumel thermocouples arranged in parallel. Each thermocouple was made from $0.51 \mathrm{~mm}$ diameter wire.

A sprinkler head with an activation temperature of $71^{\circ} \mathrm{C}$ and two different size brass discs, used to simulate faster response sprinkler heads, were used in tests 2 to 6 . Each disc had a $0.51 \mathrm{~mm}$ chrome1-alumel thermocouple soldered 
on its surface. Description of these discs is given in table 6. Location of the discs is given in table 5. Test $\mathrm{Rl}$ did not have a sprinkler nor brass disc. The sprinkler in test $\mathrm{R} 3$ had a discharge rate of $1.4 \mathrm{l} / \mathrm{s}$ (22 gal/min) corresponding to an operating water pressure of $103,100 \mathrm{~Pa}$ (15 psi). The other room tests used a dry sprinkler where the pipe was pressured with air to 34,400 $\mathrm{Pa}$ (5 psi). In addition, two types of Ionization smoke detectors were used in test 6. The description and location of these two detectors in the room are given in table 7 .

\section{RESULTS AND DISCUSSION}

\subsection{Open Burn Fires}

Results for the six open burn fires are given in figures 4 to 7 and in tables 8 and 9. Rate of heat release histories for the tests with no wall behind the bed, runs 4 and 6 , are shown in figure 4. The data indicated that the chronological development of the fire was similar for these two runs. Even though care was taken to assure repeatability between repeat runs, differences in the preparation of the bedding could result in considerable variation in fire development. This is apparent in figure 5, which showed the rate histories for runs 1 and 3 with the gypsum board lined wall. Both runs had two distinct stages of fire development. However, run 3 took longer to reach the peak development at each stage with the peak rate of heat release at each stage being almost twice as great as that for run 1 .

Differences in the stacking of the trash in the wastebasket, used as the fire initiation source, were believed to be unfmportant. Once match 1gnition 
of the trash occurred, the flames were observed to quickly involve the bedding. From that point, fire spread along the top and bottom surface of the bed determined the subsequent behavior of the fire.

Figure 6 shows the heat release rate histories for test 2 and its repeat run, test 5, with the plywood wa11. Again, two distinct stages of fire growth occurred in both tests. The second stage of development for run 2 was less pronounced and occurred at a later time than that for run 5. However, both fires were found to visually exhibit similar development and, except for the time delay in the second peak for run 2, both fires had roughly similar heat release rate histories. The heat release rate data for all six open tests are superimposed together in figure 7. All of the tests experienced two distinct stages of development. The first stage 1nvolved the bedding and the subsequent exposed parts of the matress including the cloth covering on the bottom of the box spring. The rest of the mattress and box spring then smolders until sufficient heat was built to involve the remaining combustible material, resulting in the second stage of the fire development. Except for test 1 and the time differences to reach peak fire growth, all the tests looked similar. The duration of the second stage was longer in tests 2 and 5 than that for the other tests. This is to be expected as the plywood wall in tests 2 and 5 became fully involved and contributed heavily to fire at that point. Aside from this difference, the presence of a wall behind the bed did not have a significant effect on the burning behavior of the furnishing arrangement. 


\subsection{Room Burn Fires}

Figures 8 to 15 and tables 6 to 11 summarize the results for the six room fire tests. A comparison with open fires of the same furnishing arrangement is made in section 3.2.1. Smoke detector response times and sprinkler activation times and their comparisons with response times for the brass discs, which simulated fast response sprinkler heads, are discussed in section 3.2.2. The effect of closing and subsequent reopening of the room on the fire development in test $\mathrm{R} 6$ is discussed in section 3.2.3.

Aside from room test R3 which was extinguished early in the test and test R6, which had the doorway closed for over $900 \mathrm{~s}$, the room fire tests attained flashover between 233 and 615 s. Room flashover in test 6 occurred at $1421 \mathrm{~s}$ or at a time lapse of $462 \mathrm{~s}$ after the reopening of the room. Both peak interior and doorway air temperatures reached we 11 over $800^{\circ} \mathrm{C}$ following flashover in these tests. Peak heat release rates reached as high as $2.5 \mathrm{MW}$ and 7.0 MW for the room lines with gypsum board and plywood, respectively. Total heat production over a $1800 \mathrm{~s}$ duration ranged from 580 to $940 \mathrm{MJ}$ for the room with the gypsum board and from 850 to $2250 \mathrm{MJ}$ for the room with the plywood. Peak flux measurements at the floor ranged from 35 to $130 \mathrm{~kW} / \mathrm{m}^{2}$ for the room fires. In all six room tests, the fraction of heat release leaving the room at the time of peak fire development varied between 0.19 to 0.88 with the average being 0.47 . 


\subsubsection{Comparison with Open Fires}

The rate histories for the two room fires with the gypsum board walls and opened doorway, tests $R 1$ and $R 4$, exhibited a two stage development similar to that found in the open fire tests. Chronologically, the occurrence of each stage in test $R 1$ matched those for the open fire tests 03,04 , and 06 . However, the occurrence of the first stage in test R4 was delayed by $370 \mathrm{~s}$. The bedding in all of the open and room fires were left in considerable disarray. In $\mathrm{R} 4$, the bedding may have been left tidier than in the other tests, resulting in a slower fire spread along the bedding.

Although the early stage fires in the room and in the open were similar. the fires conducted in the room eventually and rapidly became more severe than the fires in the open. In a room fire, the hot combustion products collect in the room, and once the upper surface and upper gas/smoke layer temperature increased to levels of the order of a few hundred ${ }^{\circ} \mathrm{C}$ above ambient, the thermal radiation reinforces the burning behavior of the furnishings. Table 9 shows that the peak incident fluxes taken at about bed height near the foot of the bed (location 4 in figure 3), were much higher for the room tests than those for the open fires. For the room tests, where early extinguishment did not occur, these flux levels ranged from 130 to $220 \mathrm{~kW} / \mathrm{m}^{2}$ as compared with levels of about $20 \mathrm{~kW} / \mathrm{m}^{2}$ for the open tests.

A comparison of figure 4 and figures 8 and 9 indicates that up to the time of ignition of ceiling/wall surfaces (in the present tests, this involved ignition of the exposed paper lining of the gypsum board ceiling) the open burn and room burn rates-of-heat-release were substantially similar. 
The data in figure 9 for the room burn with the gypsum wall showed that the first 2 MW spike, which is associated with the ceiling and upper wall paper lining burnout, occurred at approximately 240 and $600 \mathrm{~s}$ into tests Rl and $\mathrm{R} 4$, respectively. The first open-burn-type of rate-of-heat-release "bump" for R4 at $240 \mathrm{~s}$ (compare to the $240 \mathrm{~s}$ open burn bumps of figure 4) was apparently not of a large enough amplitude and/or of a long enough duration to lead to the ceiling ignition which eventually did occur at approximately 600 s. However, the similar open-burn-type of threat in the "identical" Rl room burn did cause an ignition of the ceiling at 240 s followed immediately by the 2 MW spike under discussion.

In both $\mathrm{Rl}$ and $\mathrm{R} 4$, the burnout of the relatively small contribution of fuel associated with the paper lining on the exposed gypsum ceiling and upper wall occurred over a time interval of approximately $60 \mathrm{~s}$. In neither case did this appear to lead to a sustained significant enhancement in the rate-ofburning of the furnishings over that of the open burn tests. On the other hand, at the onset of the second stage energy release rate surge (approximately $1.2 \mathrm{MW}$ at $660-720 \mathrm{~s}$ per figure 4), the plot of figure 9 indicates that significant enhancement of the furnishing's burning did occur in the $\mathrm{R} 4$ test, leading to a peak burning rate of $2.3 \mathrm{MW}$.

For the plywood lined room burns, R2 and R5, figure 8 showed that the increased burning of the furnishings associated with the initial open burn bump of figure 4 led to ignition and sustained burning (approximately 3008 duration) of the significant mass of combustible wall lining. This in turn resulted in a flashover at about $290 \mathrm{~s}$ and, no doubt, to an appreclable enhancement of the rate of burning of the furnishings. 
Table 9 shows that for the open fire tests, the peak concentration of smoke, given in terms of optical density divided by the path length of the light obscuration, $0 . D / \mathrm{m}$, varied from 1.0 to 1.9 and did not depend on the presence or combustibility of the wall. The integrated smoke production, represented by the extinction cross section $\mathrm{E}$, also was unaffected by the wall behind the bed. A further description of $E$ and its relationship with optical density are given in Appendix A.2 of this report. The E values for the six open fires ranged from 2020 to $2230 \mathrm{~m}^{2}$. The effect of the room on peak smoke concentration and total smoke production was not noticeable for the room tests R1, R4, and R6 having the gypsum board lining. These tests had $0 . D_{\cdot} / \mathrm{m}$ levels from 1.3 to 1.5 and $E$ values of 1850 to $2430 \mathrm{~m}^{2}$. However, for the room fires with the plywood lining, the peak $0 . \mathrm{D} . / \mathrm{m}$ ranged from 2.1 to 3.0 and the extinction cross section values reached $4190 \mathrm{~m}^{2}$.

As for the generation of carbon monoxide $(\mathrm{CO})$, room fires resulted in much higher peak mass flow rates than those for the open fires of the same room arrangements of furnishing and interior finish materials. Peak concentrations of $\mathrm{CO}$ varied from 1.5 to $2.1 \mathrm{~g} / \mathrm{s}$ in the open tests and from 4.6 to $23.5 \mathrm{~g} / \mathrm{s}$ in the room tests. However, the total production of $\mathrm{co}$ over a $1800 \mathrm{~s}$ burn duration was about the same for both open and room fire tests. Total generation of $\mathrm{CO}$ varied from 1.39 to $1.71 \mathrm{~kg}$ in the open tests and ranged from 1.48 to $2.38 \mathrm{~kg}$ for the room tests over the $1800 \mathrm{~s}$ period.

\subsubsection{Sprinkler Response and Smoke Detection}

Table 6 summarizes the response times for the sprinklers used in tests 2 through 6 and the two smoke detectors used in test 6 . Even though run RI in 
table 10 showed that room flashover could be reached in as early as $233 \mathrm{~s}$, the sprinkler activation time for run R3 in table 6 showed that an adequate sprinkler system could easily extinguish the fire at its incipient stage. Included in the table are the response times to reach $71^{\circ} \mathrm{C}$ for the brass discs, used to simulate faster response sprinkler heads and a comparison with times from a $0.51 \mathrm{~mm}$ thermocouple to reach the same temperature. As expected, the thermocouple response time increased with thermocouple location away from the rear wall where the fire was concentrated. Differences in air temperatures measured across the room at the $127 \mathrm{~mm}$ level below the ceiling were pronounced. The thermocouple over the doorway on the front inside wall took from 12 to $25 \mathrm{~s}$ longer to reach $71^{\circ} \mathrm{C}$ than the one on the rear wall for tests 2 to 6. The brass discs had longer response times than the thermocouples due to the former's larger size and thickness. The average response time for the small disc was $19 \mathrm{~s}$ longer than the thermocouple times. For runs 2 to 5, the average response times for the fusible link and large discs were 97 and $53 \mathrm{~s}$ longer, respectively, than that for the small disc. In run 6, the doorway was closed upon activation of the doorway smoke detector at $22 \mathrm{~s}$. Response of the brass discs was similar to those in the other tests, but the sprinkler was not activated until $1163 \mathrm{~s}$, which was $203 \mathrm{~s}$ after the time the door was manual1y reopened. This compared with a time of $204 \mathrm{~s}$ from the start of test $\mathrm{R} 4$ with the same room lining material and a fully opened doorway.

The response times for both ionization detectors were 13 to $15 \mathrm{~s}$, we 11 ahead of the fastest time of $45 \mathrm{~s}$ for the small brass disc on the rear wall closest to the fire. The small difference between the response times for the two detectors can not be considered statistically meaningful without performing additional testing. Intuitively, the ceiling unit was expected to respond 
first due to its proximity to the fire, providing the units at hoth the celling and doorway locations have identical sensitivities.

\subsubsection{Effect of Door Closure on Fire}

When the doorway smoke detector in test 6 activated at $22 \mathrm{~s}$, the door was manually closed. During this period, only the wastebasket and the bed sheet and pillow case immediately adjacent the wastehasket were involved. Interior air temperatures near the celling then slowly climbed to a peak of about $180^{\circ} \mathrm{C}$ at $110 \mathrm{~s}$, subsided, and did not climb again until after the door was reopened. The rate of heat release from the fire and flux levels at the floor did not rise substantially until after $1400 \mathrm{~s}$. Carbon monoxide and smoke from the room exhibited a sudden rise when the door was reopened at $960 \mathrm{~s}$. then subsided, and did not begin to greatly increase until about $1400 \mathrm{~s}$. The carbon monoxide concentrations at the 0.30 and $1.52 \mathrm{~m}$ heights in the room are given in table 11 for the time intervals prior to the door closing, during the perlod the room was closed, and after reopening of the room. The results showed that CO concentrations were much higher during the well ventilated phase of active burning than those for the fire initiation stage and the smoldering combustion period when the door was closed. The highest concentration of carbon monoxide in the room was 6.3 percent which occurred at $1460 \mathrm{~s}$ at the $1.52 \mathrm{~m}$ height.

\subsubsection{Mass Flow Calculations}

Mass flow out the doorway was calculated using three methods, denoted here as the $\Delta T, P T$, and VT methods. Mass flow using the $\Delta T$ method [8], based 
on interior and doorway air temperatures from the room fire, is given by the formula

$$
\dot{M}_{g}=C W \rho_{0} T_{0} \int_{N}^{H}\left(\frac{2 g}{T_{D}} \int_{N}^{Z}\left(\frac{1}{T_{0}}-\frac{1}{T_{I}}\right) d Z^{\prime}\right) d Z
$$

where: C - opening flow coefficient of 0.73

$$
\begin{aligned}
& g \text { - gravitational acceleration } \\
& H \text { - opening height } \\
& \dot{M}_{g} \text { - rate of air flow } \\
& N \text { - height of neutral plane } \\
& T_{O} \text { - ambient air temperature } \\
& T_{D} \text { - doorway air temperature } \\
& T_{I} \text { - interior air temperature } \\
& W \text { - opening width } \\
& Z \text { - vertical coordinate } \\
& \rho_{O} \text { - ambient air density }
\end{aligned}
$$

The PT and VT methods rely on a vertical integration of the flow in the doorway using doorway air temperatures and velocities calculated from pressure measurements and Bernoulli's equation. For the PT method, the pressures are made on the interior wall surface in the room. For the VT method, the pressure measurements, and hence velocities, are made along the vert1cal centerline of the doorway. The equation used for these two cases is

$$
\dot{\mathrm{M}}_{\mathrm{g}}=\mathrm{CW}\left(2 \rho_{0} \mathrm{~T}_{0}\right)^{1 / 2} \int_{\mathrm{N}}^{\mathrm{H}}\left(\frac{\mathrm{P}}{\mathrm{T}}\right)^{1 / 2} \mathrm{dZ}
$$


where $T_{0}, T_{D}, W, Z$, and $\rho_{0}$ are the same as before, $P$ is the air pressure above ambient measured at the doorway, and $C$ is the flow coefficient. For the PT method, $C$ is also 0.73 . For the VT method, $C$ is more 1ike 0.8 as Quintiere and McCaffrey [9] and Tu and Babrauskas [10] have found that calculations of mass flow based on outflow centerline velocities could be 20 to 30 percent greater than the actual flow.

Comparisons of mass flow calculated with the three methods are given in figures 12 to 15 for tests R1 to R5. In general, the results showed rough agreement with each other.

\section{SUMMARY AND CONCLUSIONS}

The burning behavior of a furnishing arrangement, representative of those in park lodging facilities, was studied inside a $2.44 \mathrm{~m} \mathrm{x} 3.66 \mathrm{~m} \times 2.44 \mathrm{~m}$ high room. The same arrangement was burned outside the room with and without the head of the bed adjacent to a single $2.44 \mathrm{~m} \times 2.44 \mathrm{~m}$ high wa11. The furnishings consisted of a double bed, headboard and night table for a total combustible weight of $53.7 \mathrm{~kg}$. Interior finish materials for the room and for the wall were gypsum board and $6.4 \mathrm{~mm}$ plywood. Fire initiation was match flame ignition of trash in a small wastebasket between the night table and the bed. The findings from this series of tests are given below.

1. Park lodging furnishings could pose a fire hazard. It was demonstrated that a representative furnishing arrangement could result in room flashover in as early as $233 \mathrm{~s}$ with a peak heat release rate of over $2 \mathrm{MW}$. 
2. Wood paneling in the room has been shown to increase the peak heat release rate to $7 \mathrm{MW}$.

3. The presence or combustibility of a wall behind the bed did not have a significant effect on the burning rate nor on the production of smoke and carbon monoxide from the furnishing fires. Differences due to the wall were within the experimental scatter found between repeat runs of each test.

4. Prior to the ignition of the exposed combustible celling surface, the effect of a room on the rate of burning of the furnishings did not appear to be significant. However, subsequent to celling surface Ignition, significant enhancement in the burning rate of furnishings was indicated in all open door room burn tests with one exception (RI).

5. Much higher concentrations of carbon monoxide occurred inside the room for a well ventilated fire than those for a closed room fire. Higher carbon monoxide levels occurred at the $1.5 \mathrm{~m}$ height than that at the $0.30 \mathrm{~m}$ height in the room.

6. A sprinkler in the room could extinguish a fire at its incipient stage. Sim1larly, automatic door closing devices activated by smoke detectors could contain the fire and prevent room flashover. These results, nevertheless, should not imply complete fire safety in such protected lodging as the loss of electrical power or disruption of the water supply by fire or by natural disasters cannot be discounted. 
7. Mass flow out of the doorway, calculated from three computational techniques, showed rough agreement with each other.

\section{ACKNOWLEDGMENTS}

The work was partially supported by the U.S. Park Service. Appreciation is expressed to Messrs. C. Veirtz, M. Womble, and 0. Owens who built the test room, prepared the test arrangement, and performed the actual testing; to Mr. J.N. Breese for the data reduction and preparation of most of the figures in the report; and to Dr. L.Y. Cooper for his help in establishing the test furnishing arrangement.

\section{REFERENCES}

1. Cooper, L.Y., A Mathematical Model for Estimating Available Safe Egress Time in Fires. Fire and Materials, Vol. 6, Nos. 3 and 4; 1982.

2. Fang, J.B., Fire Performance of Selected Residential Floor Constructions Under Room Burnout Conditions. Nat. Bur. Stand. (U.S.) NBSIR 80-2134; December 1980.

3. Babrauskas, V., Combustion of Mattresses Exposed to Flaming Ignition Sources, Part I. Ful1-Scale Tests and Hazard Analysis. Nat. Bur. Stand. (U.S.) NBSIR 77-1290; September 1977.

4. Huggett, C., Estimation of Rate of Heat Release by Means of Oxygen Consumption Measurements. Fire and Materials; Vol. 4, 1980.

5. Parker, W.J., Calculations of the Heat Release Rate by Oxygen Consumption for Various Applications. Nat. Bur. Stand (U.S.) NBSIR 81-2427-1; March 1982.

6. Lee, B.T., Effect of Ventilation on the Rates of Heat, Smoke, and Carbon Monoxide Production in a Typical Jail Cell Fire. Nat. Bur. Stand. (U.S.) NBSIR 82-2469; March 1982.

7. McCaffrey, B.J. and Heskestad, G., A Robust Bidirectional Low-Velocity Probe for Flame and Fire Application. Combustion and Flame, Vol. 26; 1976. 
8. Steckler, K.D., Quintiere, J.G. and Rinkinen, W.J., Flow Induced by Fire in a Compartment. Nineteenth International Symposium on Combustion, Halfa, Israel; August 1982.

9. Quintiere, J. and McCaffrey, B., The Burning of Wood and Plastic Cribs in an Enclosure, Vol. I. Nat. Bur. Stand. (U.S.) NBSIR 80-2054;

November 1980 .

10. Tu, K.M. and Babrauskas, V., The Calibration of a Burn Room for Fire Tests on Furnishings. Nat. Bur. Stand. (U.S.) Technical Note 981 ; Decerber 1978. 


\section{A.1 Calculation of Heat Release Rate from Oxygen Depletion Measurement}

The formulae given here are taken from a report by Parker [5]. The rate of heat release from a room fire can be expressed as:

$$
\dot{Q}=\mathrm{Ex}_{\mathrm{O}_{2}}^{\circ} \dot{\mathrm{m} \emptyset} \mathrm{w}_{\mathrm{O}_{2}} / \mathrm{w}_{\mathrm{air}}
$$

where: $\quad \dot{Q}=$ rate of heat released from the fire room, MW,

$E=$ heat per unit mass of oxygen consumed by the burning of materials normally used in the construction and furnishing of rooms. $\mathrm{MJ} / \mathrm{kg}$. A value of $13.2 \mathrm{MJ} / \mathrm{kg}$ was chosen based on a study by Huggett [4].

$$
\begin{aligned}
\mathrm{x}_{\mathrm{O}_{2}}^{\mathrm{O}} & =\text { oxygen concentration in ambient air, moles oxygen/moles air, } \\
\dot{\mathrm{m}} & =\text { mass flow rate of air from fire room, } \mathrm{kg} / \mathrm{s}, \\
\mathrm{W}_{\mathrm{O}_{2}} & =\text { molecular weight of oxygen, } \\
\mathrm{W}_{\mathrm{alr}} & =\text { molecular weight of air, and } \\
\emptyset & =\text { oxygen depletion of the air. }
\end{aligned}
$$




$$
\phi=\frac{x_{0_{2}}^{o}-x_{0_{2}}^{A}}{x_{O_{2}}^{o}\left(1-x_{0_{2}}^{A}\right)}
$$

if the $\mathrm{CO}_{2}$ is trapped ahead of the oxygen analyzer, and

$$
\phi=\frac{x_{O_{2}}^{\mathrm{O}}-\mathrm{x}_{\mathrm{O}_{2}}^{\mathrm{B}} /\left(1-\mathrm{x}_{\mathrm{CO}_{2}}\right)}{\mathrm{x}_{\mathrm{O}_{2}}^{\mathrm{O}}\left[1-\mathrm{x}_{\mathrm{O}_{2}}^{\mathrm{B}} /\left(1-\mathrm{x}_{\mathrm{CO}}\right)\right]}
$$

when $\mathrm{CO}_{2}$ is not trapped,

where $\mathrm{X}_{\mathrm{O}_{2}}^{\mathrm{A}}$ = measured oxygen concentration with $\mathrm{CO}_{2}$ trapped out,

$$
\begin{aligned}
& \mathrm{X}_{\mathrm{O}_{2}}^{\mathrm{B}}=\text { measured oxygen concentration when } \mathrm{CO}_{2} \text { is not trapped, and } \\
& \mathrm{X}_{\mathrm{CO}_{2}}=\text { measured concentration of } \mathrm{CO}_{2} \cdot
\end{aligned}
$$

\section{A.2 Quantification of Smoke from Room Fire Tests}

The integrated smoke production in the room fire tests can be represented by the extinction cross section generated. This extinction cross section, $E\left(m^{2}\right)$, is equal to the total mass of the smoke generated, $m(\mathrm{~kg})$, times the specific extinction coefficient, $\mathrm{K}\left(\mathrm{m}^{2} / \mathrm{kg}\right)$. The coefficient $\mathrm{K}$ is a property of the smoke rather than a measure of its quantity. The relationship between 
E and the optical density, O.D., is given below. The optical density is defined as

$$
\text { O.D. }=\log _{10} \frac{100}{\mathrm{~T}}=\log _{10} \mathrm{e}^{\mathrm{K} \rho \mathrm{L}}=0.434 \mathrm{~K} \rho \mathrm{L}
$$

where $T$ is the percent transmission of the smoke meter, $L$ is its path length in $\mathrm{m}$, and $\rho\left(\mathrm{kg} / \mathrm{m}^{3}\right)$ is the mass concentration of the smoke. Thus, $\mathrm{E}$ is given by

$$
\mathrm{E}=\mathrm{K} \rho \mathrm{V}=2.3 \mathrm{~V}\left(\frac{0 . \mathrm{D}_{.}}{\mathrm{L}}\right)
$$

where $V\left(\mathrm{~m}^{3}\right)$ is the volume of the smoke-filled space. Since $\dot{V}\left(\mathrm{~m}^{3} / \mathrm{s}\right)$, the volume flow of smoke-filled air from the room and the quantity O.D. change during the test, $\mathrm{E}$ is determined by integrating over the duration of the test, $t(s)$, or

$$
E=2.3 \int_{0}^{t} \dot{V}\left(\frac{O . D_{0}}{L}\right) d t
$$

Equation (3) can also be related to measurements performed in the ASTM E 662 test with the smoke density chamber*. The quantity $\mathrm{E}$ is equivalent to the product of the specific optical density measured in that test and the specimen surface area employed in the test. Equation (2) can be used to estimate the average O.D. per meter beyond the room of fire origin if the smoke is dispersed over a known volume and the effect of smoke deposition and coagulation is neglected.

*Standard Test Method for Specific Optical Density of Smoke Generated by Solid Materials. ASTM E 662. Philadelphia, PA: American Society for Testing and Materials; 1979. 


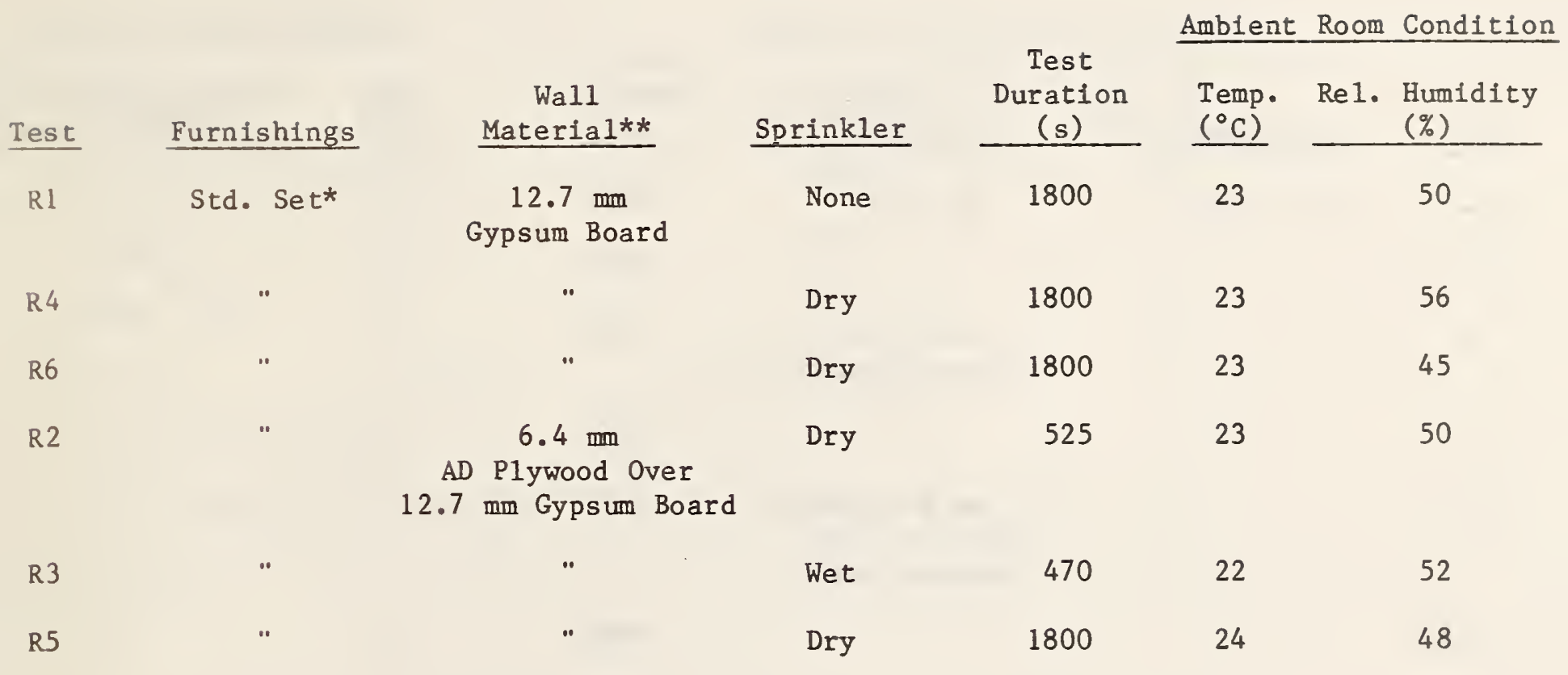

* Standard set consisted of one double bed, a wood headboard, and one wood night table. A wastebasket filled with trash, positioned between the bed and night table, served as the ignition source.

**Celling material was $15.9 \mathrm{~mm}$ fire-resistant gypsum board. 


\begin{tabular}{|c|c|c|c|c|c|}
\hline \multirow[b]{2}{*}{ Test } & \multirow[b]{2}{*}{ Furnishings } & & \multirow[b]{2}{*}{$\begin{array}{c}\text { Test } \\
\text { Duration } \\
(s) \\
\end{array}$} & \multicolumn{2}{|c|}{ Ambient Lab. Condition } \\
\hline & & $\begin{array}{c}\text { Wall Behind } \\
\text { Headboard }\end{array}$ & & $\begin{array}{l}\text { Temp. } \\
\left({ }^{\circ} \mathrm{C}\right) \\
\end{array}$ & $\begin{array}{c}\text { Relative Humidity } \\
(\%)\end{array}$ \\
\hline 04 & Std. Set* & No Wall & 1800 & 22 & 32 \\
\hline 06 & $"$ & 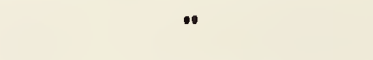 & 1800 & 21 & 38 \\
\hline 01 & $"$ & $\begin{array}{c}12.7 \mathrm{~mm} \\
\text { Gypsum Board }\end{array}$ & 1800 & 22 & 50 \\
\hline 03 & " & $\bullet$ & 1800 & 21 & 40 \\
\hline 02 & 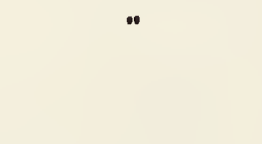 & $\begin{array}{l}6.4 \mathrm{~mm} \text { AD P1ywood } \\
\text { Over } 12.7 \mathrm{~mm} \\
\text { Gypsum Board }\end{array}$ & 1800 & 22 & 50 \\
\hline 05 & " & $"$ & 1800 & 21 & 38 \\
\hline
\end{tabular}

*Standard set consisted of one double bed, a wood headboard, and one wood night table. A wastebasket filled with trash, positioned between the bed and night table, served as the ignition source. 
Table 3. Fuel Loading in Fire Tests

Combustible Weight in Kilograms

Fuel Item

Mattress and Box Spring*

Headboard

Night Table

Bedding

Filled Wastebasket

Total Combustible Furnishing

Plywood**
Open Burns

24.7

14.4

10.6

3.2

0.75

53.7

19.5
Room Burns

$$
24.7
$$$$
14.4
$$

10.6

3.2

0.75

53.7

77.9

*Mattress and boxspring weight excluding that of the inner springs. **0nly used for open burn tests 2 and 5 and for room tests 2,3 and 5 . 
Table 4. Wastebastion Lource

Wastebasket - Polyethylene wastebasket Weight: $0.34 \mathrm{~kg}$

Trash contents, in order of stacking

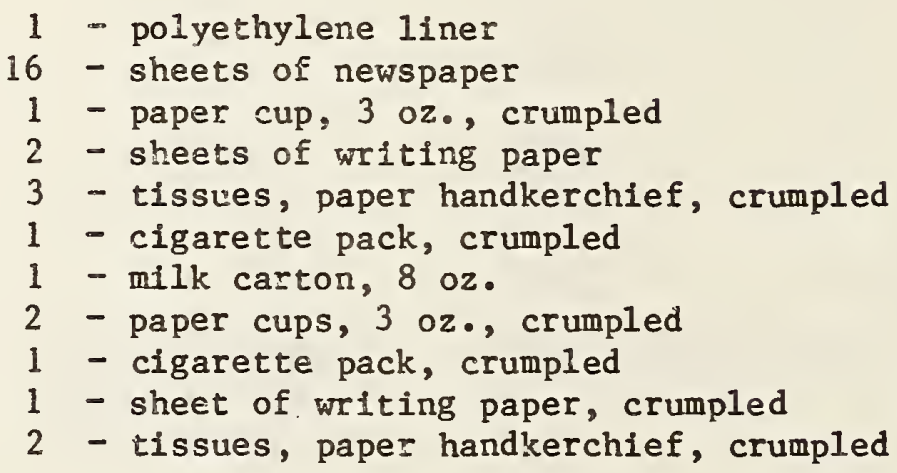

Total weight of contents: $0.41 \mathrm{~kg}$ 
1 smoke meter

1 Gas sample port $\left(\mathrm{O}_{2}, \mathrm{CO}, \mathrm{CO}_{2}\right)$

9 Velocity probes

$90.51 \mathrm{~mm}$ the rmocouples

$110.51 \mathrm{~mm}$ thermocouples and

$110.05 \mathrm{~mm}$ thermocouples

$10.51 \mathrm{~mm}$ the rmocouple

$60.51 \mathrm{~mm}$ thermocouples and

$\begin{array}{lll}6 & 0.05 \mathrm{~mm} \text { thermocouples }\end{array}$

$250.51 \mathrm{~mm}$ the rmocouples

$30.51 \mathrm{~mm}$ thermocouples

$30.51 \mathrm{~mm}$ the rmocouples

$30.51 \mathrm{~mm}$ thermocouples

2 flux meters

2 gas sample ports $\left(\mathrm{CO}, \mathrm{CO}_{2}\right)$

5 bi-directional velocity probes

1 bi-directional velocity probe

11 pressure probes
Exhaust hood

Exhaust hood

Exhaust hood

Exhaust hood

Each set of $0.51 \mathrm{~mm}$ and $0.05 \mathrm{~mm}$ thernocouples at $0.30 \mathrm{~m}$ from front wall and $0.30 \mathrm{~m}$ from left wall at the following distances below the celling (m): $0.20,0.41,0.61$, $0.81,1.02,1.22,1.42,1.63,1.83,2.03$, 2.24

$100 \mathrm{~mm}$ below center of ceiling

Each set of $0.51 \mathrm{~mm}$ and $0.05 \mathrm{~mm}$ thermocouples at the following distances below top of the doorway $(\mathrm{m}): 0.10,0.20,0.51,0.81$, $1.12,1.73$

Inlet area of exhaust hood

On small brass discs located $127 \mathrm{~mm}$ from ceiling and $127 \mathrm{~mm}$ from midway of each of the rear, left, and front wa1ls

On large brass discs located at the vicinity of the small discs

Next to brass discs at rear, left and front walls

One next to left wall, facing wastebasket, $1.93 \mathrm{~m}$ from rear wall, and $0.64 \mathrm{~m}$ above floor. The other on floor, $2.13 \mathrm{~m}$ from rear wall and $1.22 \mathrm{~m}$ from left wall

At 0.30 and 1.52 m heights, 1.93 m from rear wal1 and $0.53 \mathrm{~m}$ from left wal1

Following distances below the top of the doorway $(m): 0.20,0.51,0.81,1.12$ and 1.73

Near sprinkler

On interior of front wall, $51 \mathrm{~mm}$ from left wall at the following distances below the ceiling (m): $0.20,0.41,0.61,0.81,1.02$, $1.22,1.42,1.63,1.83,2.03$ and 2.24 
Table 6. Sprinkler Response Times

(Response time in seconds to reach $71^{\circ} \mathrm{C}$ for sprinkler fusible link and brass discs*)

Front Wa11

Side Wall

Rear Wall

\begin{tabular}{|c|c|c|c|c|c|c|c|c|c|c|}
\hline Test & $\begin{array}{c}\text { Fusible } \\
\text { Link }\end{array}$ & $\begin{array}{l}\text { Large } \\
\text { Disc } \\
\end{array}$ & $\begin{array}{l}\text { Smal1 } \\
\text { Disc }\end{array}$ & $\begin{array}{l}\text { Thermo- } \\
\text { couple }\end{array}$ & $\begin{array}{l}\text { Large } \\
\text { Disc } \\
\end{array}$ & $\begin{array}{l}\text { Smal1 } \\
\text { Disc }\end{array}$ & $\begin{array}{l}\text { Thermo- } \\
\text { couple }\end{array}$ & $\begin{array}{l}\text { Large } \\
\text { Disc }\end{array}$ & $\begin{array}{l}\text { Small } \\
\text { Disc }\end{array}$ & $\begin{array}{l}\text { Thermo- } \\
\text { couple }\end{array}$ \\
\hline $\mathrm{R} 1$ & - & -- & - & - & -- & - & -- & - & -- & -- \\
\hline $\mathrm{R} 2$ & 165 & 118 & 71 & 46 & 93 & 51 & 33 & 86 & 45 & 30 \\
\hline R3 & 167 & 130 & 94 & 78 & 115 & 78 & 68 & 105 & 76 & 66 \\
\hline R4 & 204 & 158 & 89 & 70 & 124 & 75 & 65 & 103 & 66 & 55 \\
\hline R5 & 189 & 142 & 84 & 65 & 103 & 66 & 52 & 86 & 52 & 40 \\
\hline$R 6 * *$ & 1163 & 112 & 62 & 45 & 80 & 50 & 37 & 72 & 46 & 33 \\
\hline
\end{tabular}

*Sprinkler had a side wall head and a fusible link rating (activation temp) of $71^{\circ} \mathrm{C}$. The link itself was $29.2 \mathrm{~mm}$ long, $19.2 \mathrm{~mm}$ wide, $2.7 \mathrm{~mm}$ thick, and weighed $10.0 \mathrm{gm}$. The small brass disc had a diameter of $9.8 \mathrm{~mm}$, was $0.8 \mathrm{~mm}$ thick and weighed $0.5 \mathrm{gm}$. The large brass disc had a diameter of $21.6 \mathrm{~mm}$, was $2.4 \mathrm{~mm}$ thick and weighed $7.3 \mathrm{gm}$. $* *$ In test 6 , the door was closed at $22 \mathrm{~s}$ and was not reopened until $960 \mathrm{~s}$. 
Table 7. Activation Times for Smoke Detectors in Test R6

$\begin{array}{ccc}\text { Unit* } & \text { Location } & \text { Response Time }(s) \\ P & \text { Near center of ceiling } & 15 \\ S & \text { Directly over doorway lintel, inside room } & 13\end{array}$

*Unit $P$ is a typical residential lonization type. Unit $S$ is an ionization type typically used in conjunction with automatic door closing hardware. 
Table 8. Heat Release and Heat Output Measurements

Wall

Material

R1 Gypsum Board

R4

R6

$\mathrm{R} 2$

R3 **

R5

Plywood

"

$\bullet$
Stack Peak Heat

Release Rate $Q_{M}$

(MW)

2. 1

2.3

2.5

4.1

$0.1^{+}$

7.0
Tine to

$(s)^{\mathrm{M}}$

Total Reat Over $1800 \mathrm{~s}, \int \dot{Q} d t$ (MJ)
Heat Output

Rate $h_{s}$ at

Time of $Q_{M}$ (NW)
Ratio

$h_{s} / Q_{M}$

0.19

0.48

0.32

0.88

430

140

390

\section{0}

940

$850 *$

$10 *$

2250
0.4

1.1

0.8

3.6

$0.1^{+}$

3.4
$+$

0.49

\begin{tabular}{lcccccc}
\hline 04 & No Wal1 & 1.2 & 670 & 610 & H. & - \\
06 & " & 1.1 & 720 & 640 & - & - \\
01 & Gypsum Board & 0.7 & 510 & 430 & - & - \\
03 & " & 1.3 & 690 & 640 & - & - \\
02 & P1ywood & 1.3 & 790 & 610 & - & - \\
05 & " & 1.5 & 590 & 910 & - \\
\hline
\end{tabular}

NOTES

1. $\dot{Q}$ is the heat release rate of the burning contents. For a room fire, it includes the heat released from flames extending beyond the room opening. $\dot{Q}$ is based on oxygen depletion and mass flow measurements in the stack. The peak value of $\dot{Q}$ is denoted by $\dot{Q}_{M^{\circ}}$.

2. $h_{s}$ is the heat convected from the fire. It is based on the calfbration factor of $4.66 \mathrm{kw}$ per ${ }^{\circ} \mathrm{C}$ rise in the stack the rmocouple grid.

*Test extinguished at $525 \mathrm{~s}$ with total heat (based on oxygen consumption) recorded to $600 \mathrm{~s}$. **Test extinguished at $167 \mathrm{~s}$ with total heat (based on oxygen consumption) recorded to $470 \mathrm{~s}$. +Measurement accuracy with $\pm 0.05 \mathrm{MN}$; thus ratio not meaningful.

HIn open burns, fire plume impinged on one side of hood and clung to one side of the stack inlet, rendering measurement of $h_{s}$ with the grid of thermocouples meaningless. 


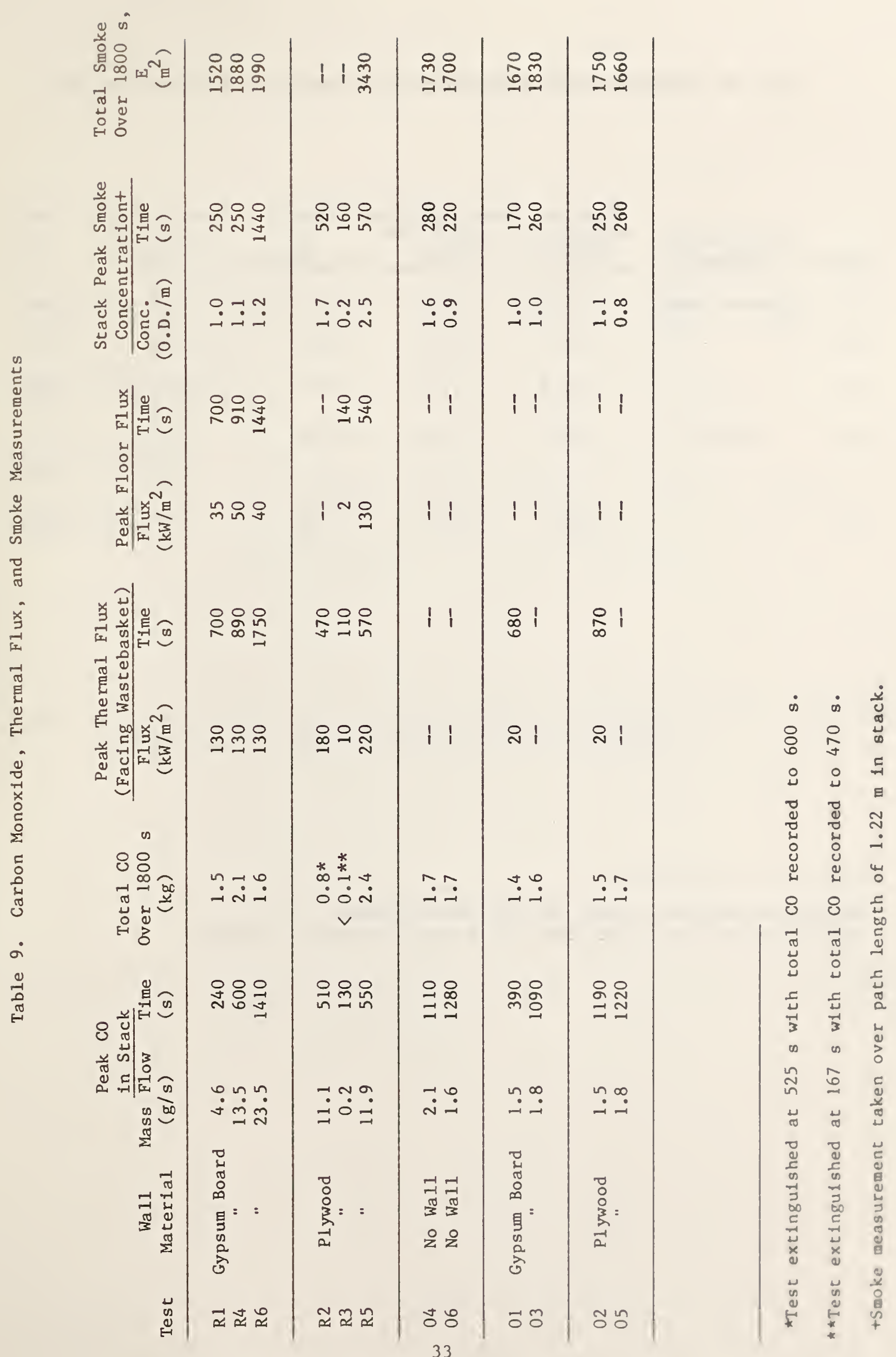


Table 10. Flashover Times and Peak Air Temperatures in Room Fire Tests

\begin{tabular}{|c|c|c|c|c|c|c|}
\hline Test & $\begin{array}{c}\text { Wall Finish } \\
\text { Material } \\
\end{array}$ & $\begin{array}{l}\text { Time to } \\
\text { Flashover } \\
\text { (s) }\end{array}$ & $\begin{array}{c}\text { Peak Interior } \\
\text { Temp. }{ }^{\mathrm{T}} \mathrm{I}^{\star *} \\
\left({ }^{\circ} \mathrm{C}\right)\end{array}$ & $\begin{array}{c}\text { Time to } \\
\mathrm{T}_{\mathrm{I}} \\
\end{array}$ & $\begin{array}{c}\text { Peak Doorway } \\
\text { Temp. T }{ }^{* t} \\
\left({ }^{\circ} \mathrm{C}\right)^{-}\end{array}$ & $\begin{array}{c}\text { Time to } \\
\mathrm{T}_{\mathrm{D}} \\
(\mathrm{s})\end{array}$ \\
\hline $\mathrm{R} 1$ & Gypsum Board & 233 & 826 & 710 & 918 & 240 \\
\hline R4 & $\bullet$ & 615 & 962 & 920 & 880 & 910 \\
\hline $\mathrm{R} 6$ & $"$ & $1421 *$ & 979 & 1720 & 1042 & 1780 \\
\hline R2 & Plywood & 293 & 953 & 520 & 848 & 400 \\
\hline R3 & $"$ & - & 192 & 160 & 186 & 160 \\
\hline R5 & $\bullet$ & 287 & 1064 & 600 & 945 & 600 \\
\hline
\end{tabular}

*This time was $462 \mathrm{~s}$ after the door was reopened. $* * 0.10 \mathrm{~m}$ down from celling and $0.10 \mathrm{~m}$ down from top of doorway. 
Table 11. Carbon Monoxide Measurements for Test R6

Peak CO Inside Room

$0.30 \mathrm{~m}$ Height $1.50 \mathrm{~m}$ Eeight Peak CO in Stack

Time Interval

(s)

Conc. Time Conc. Time

Conc.

Time

(\%) (s)

(\%) (s)

(\%)

(s)

Prior to $22 \mathrm{~s}$

$<0.2$

$-\quad<0.2$

$-$

$<0.04$

(Door Opened)

$22-960 \mathrm{~s}$

0.4

940

0.8

930

$<0.04$

(Door Closed)

$960-1800 \mathrm{~s}$

(Door Opened)

$0.5 \quad 1700$

6.3

1410

0.55

1410

Notes: The room $C O$ meter has a 10 percent range and a $\pm 0.2 \%$ accuracy. The stack CO meter has a 2 percent range and a $\pm 0.04 \%$ accuracy. 


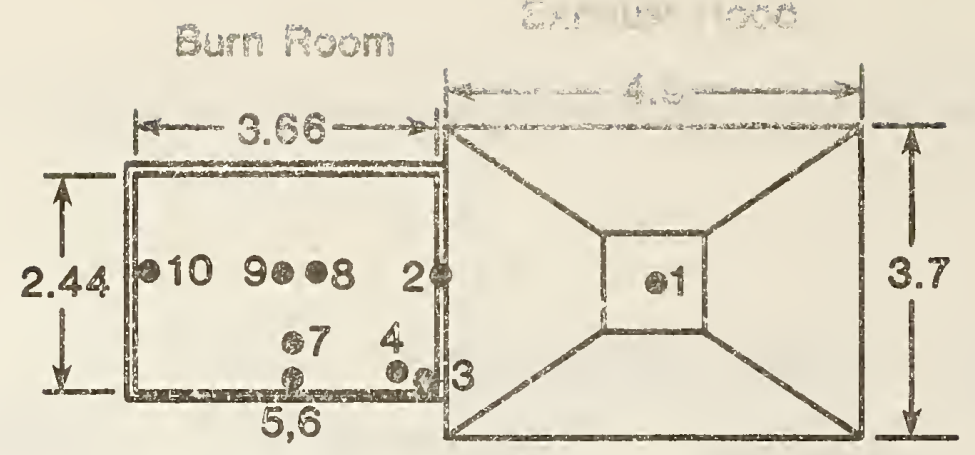

PLAN VIEW (ceiling of room removed)

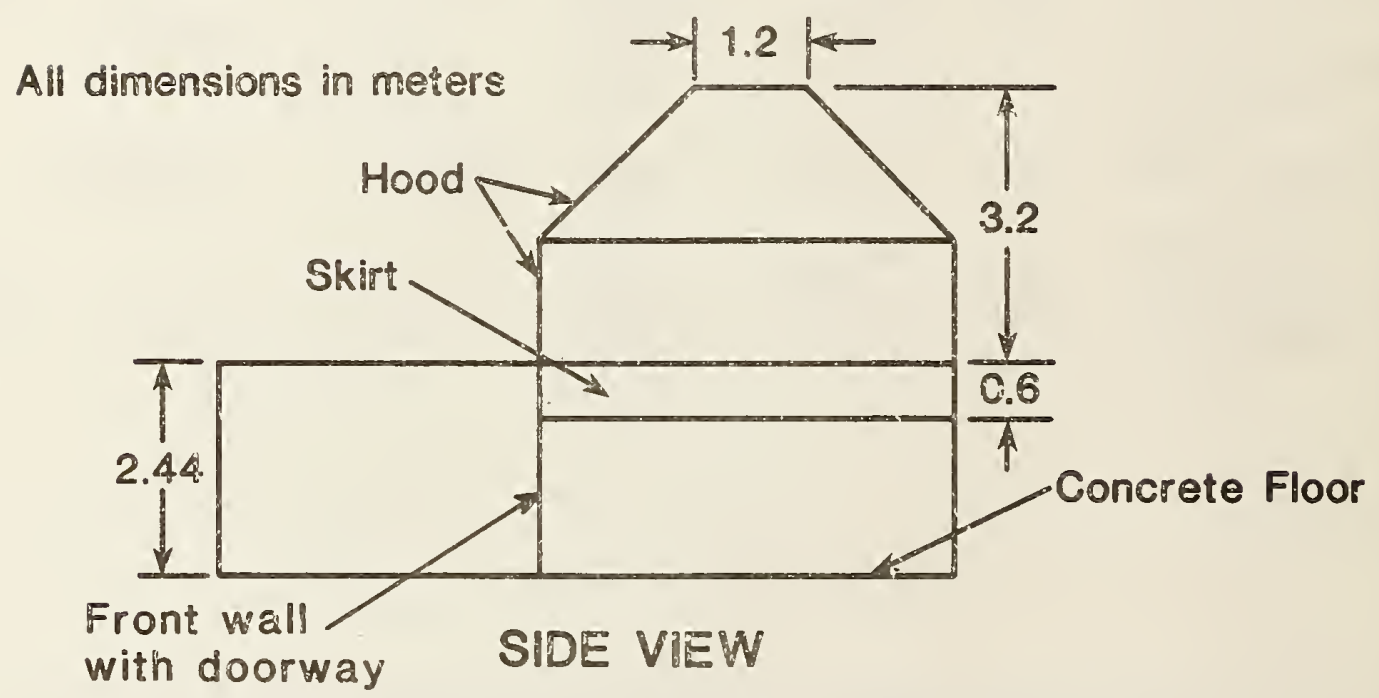

Station

Instrument

1 Gas sampling port, thermocouples, velocity prcbes, smoke meter

2 Thermocouple tree, velocity probes, sprinkler head, brass discs (simulating sprinkler heads), smoke detector

3 Pressure probes on interior wa!l

4 Thermocouple tree

5 Flux meter meter facing wastebasket

6 Thermocouple, brass discs near ceiling

7 Gas sampling ports in room

8 Flux meter on floor

9 Thermocouple near ceiling, smoke detector

10 Thermocouple, brass discs near ceiling

Figure 1. Test Room Exhaust Hood Arrangement and Instrumentation 

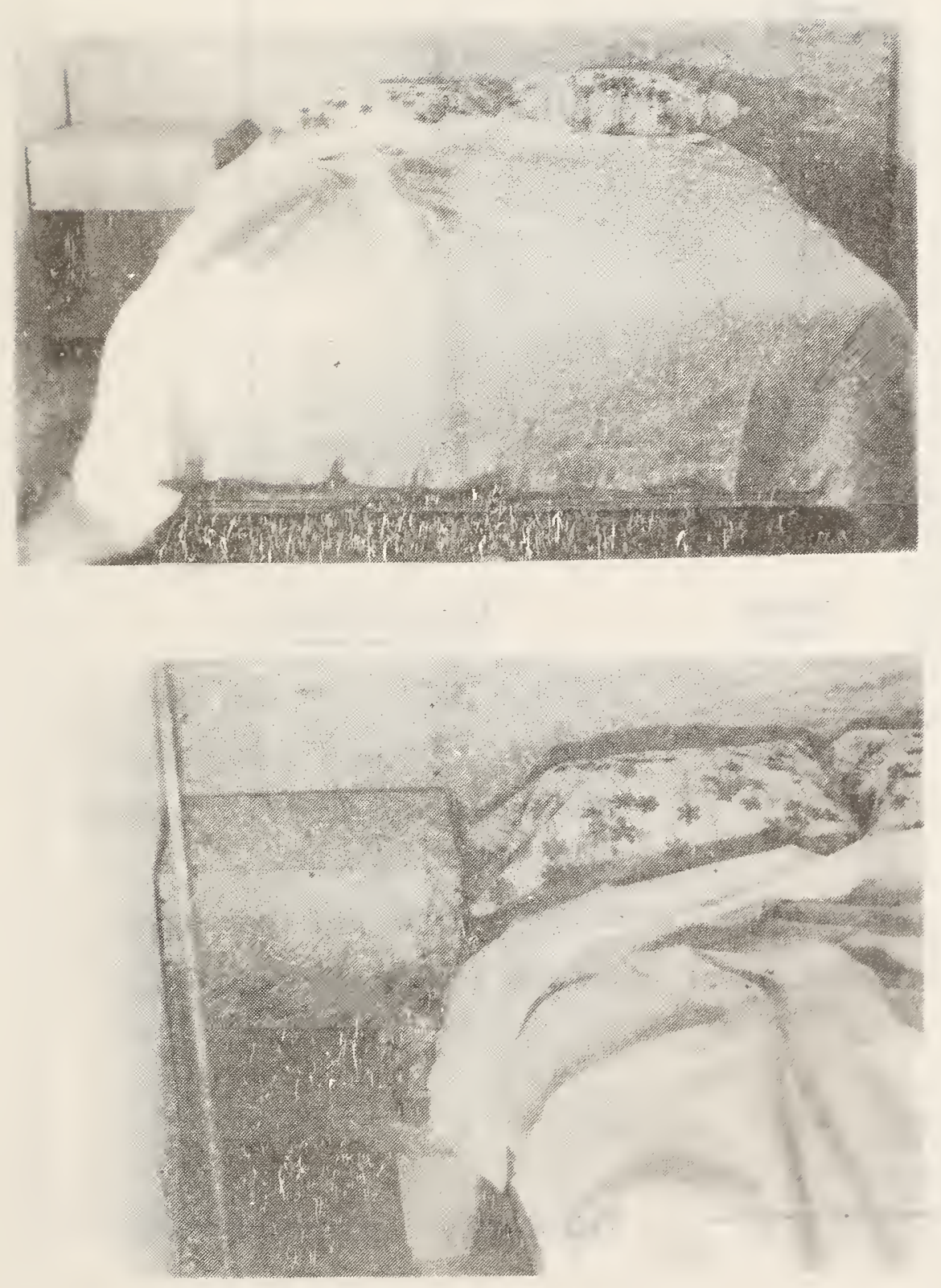

Figure 2. Furnishing Arrangement with Wastebasket Ignition Source 


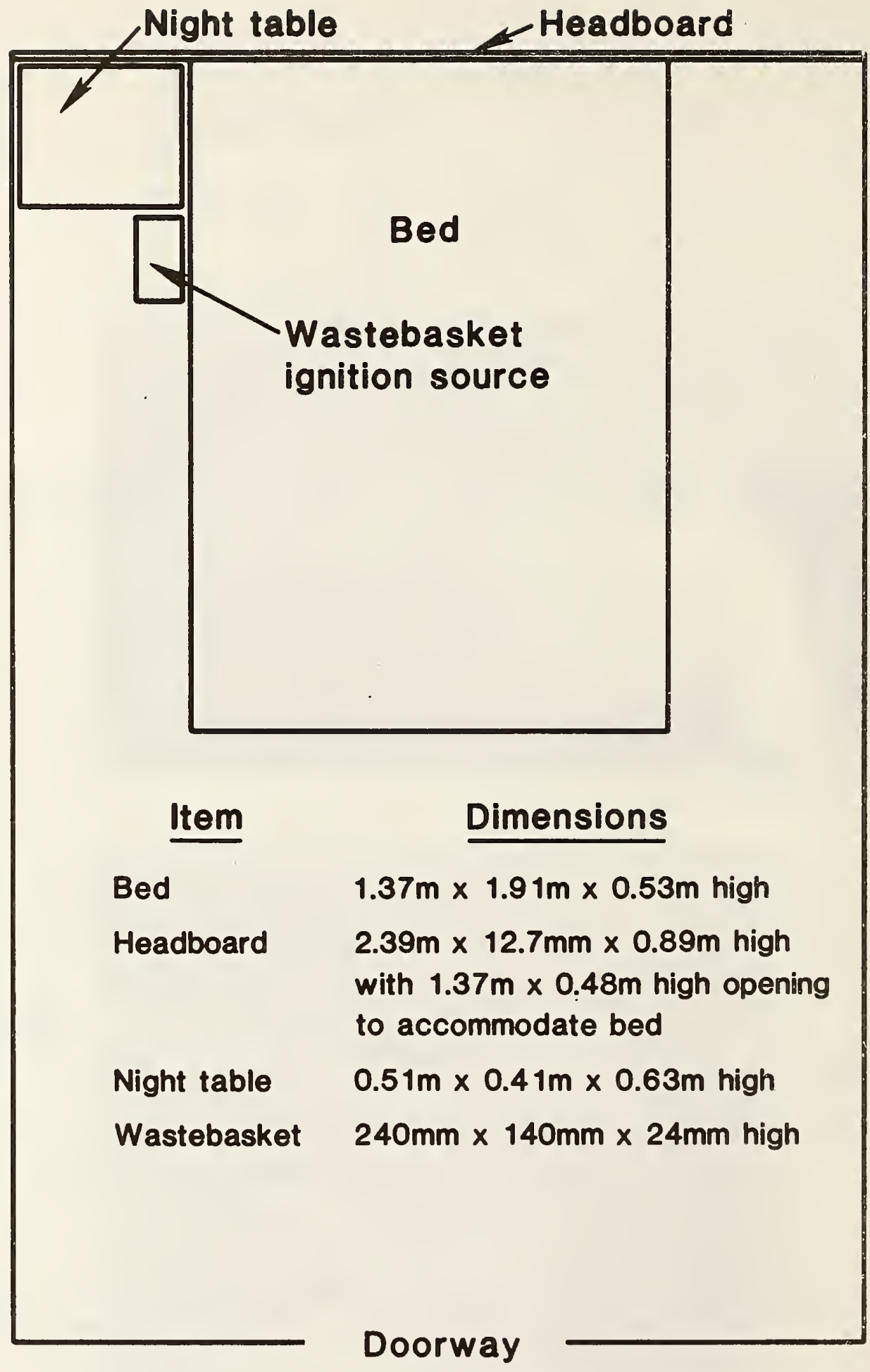

Figure 3. Plan View of Fire Test Room Arrangement 


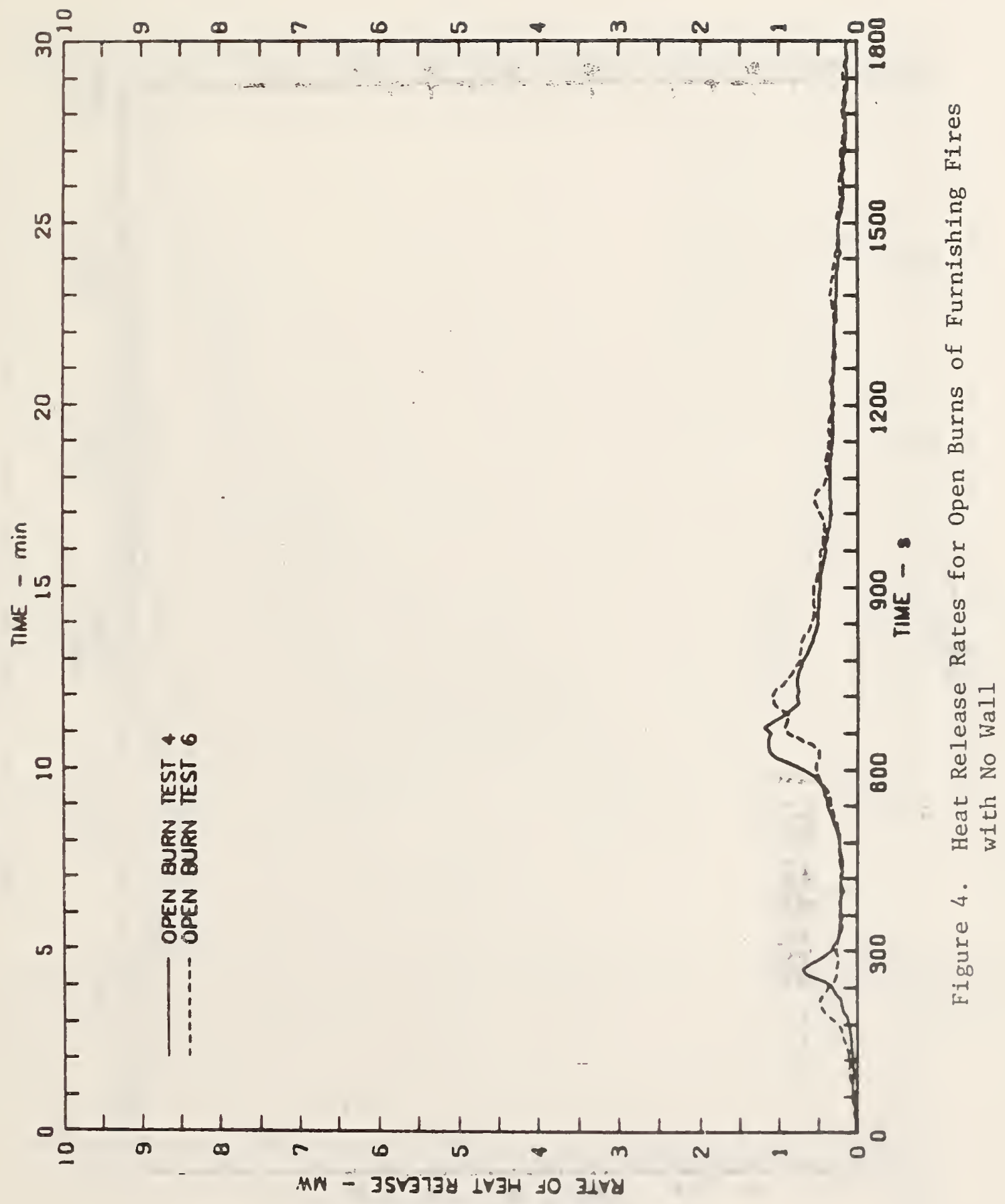




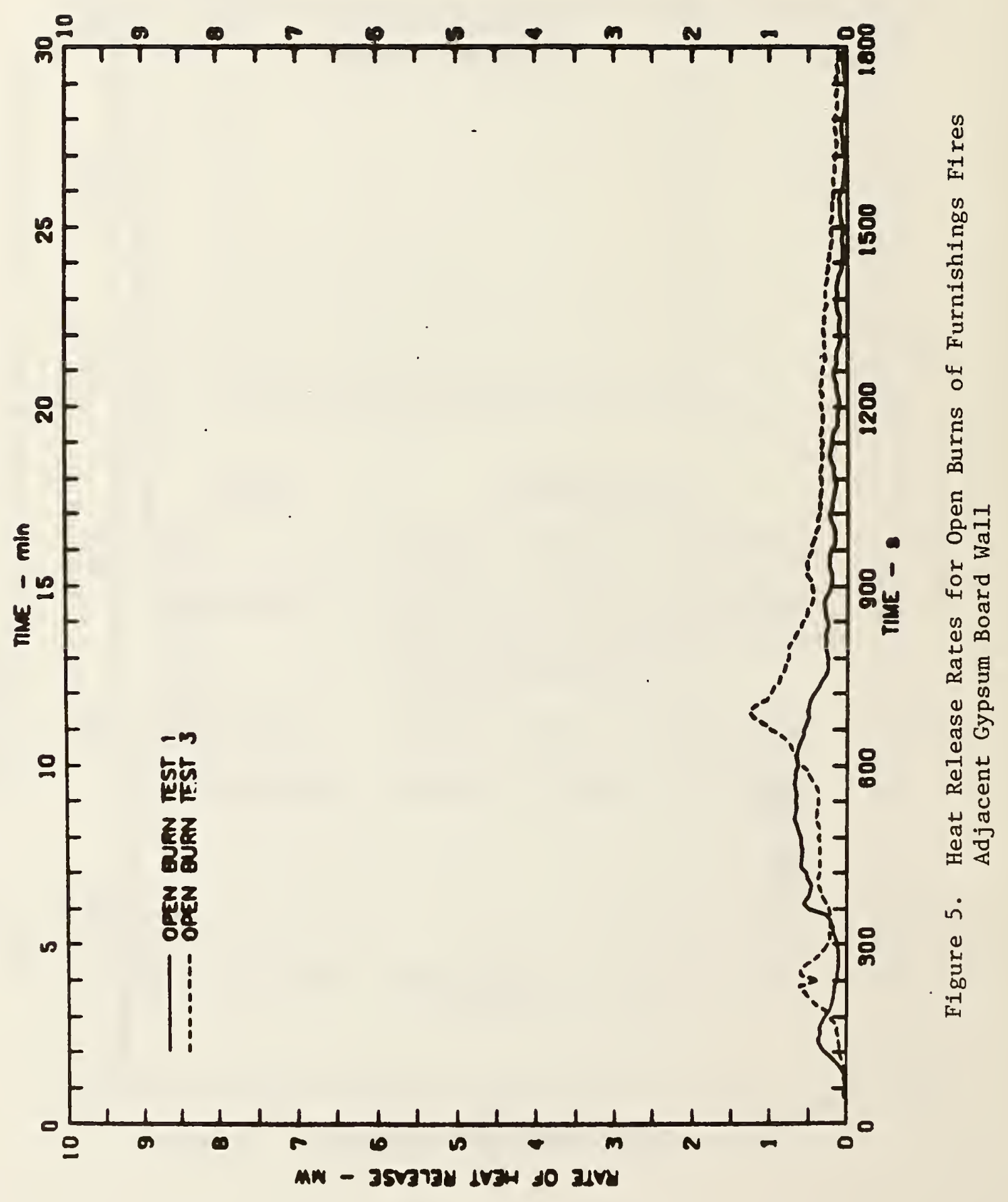




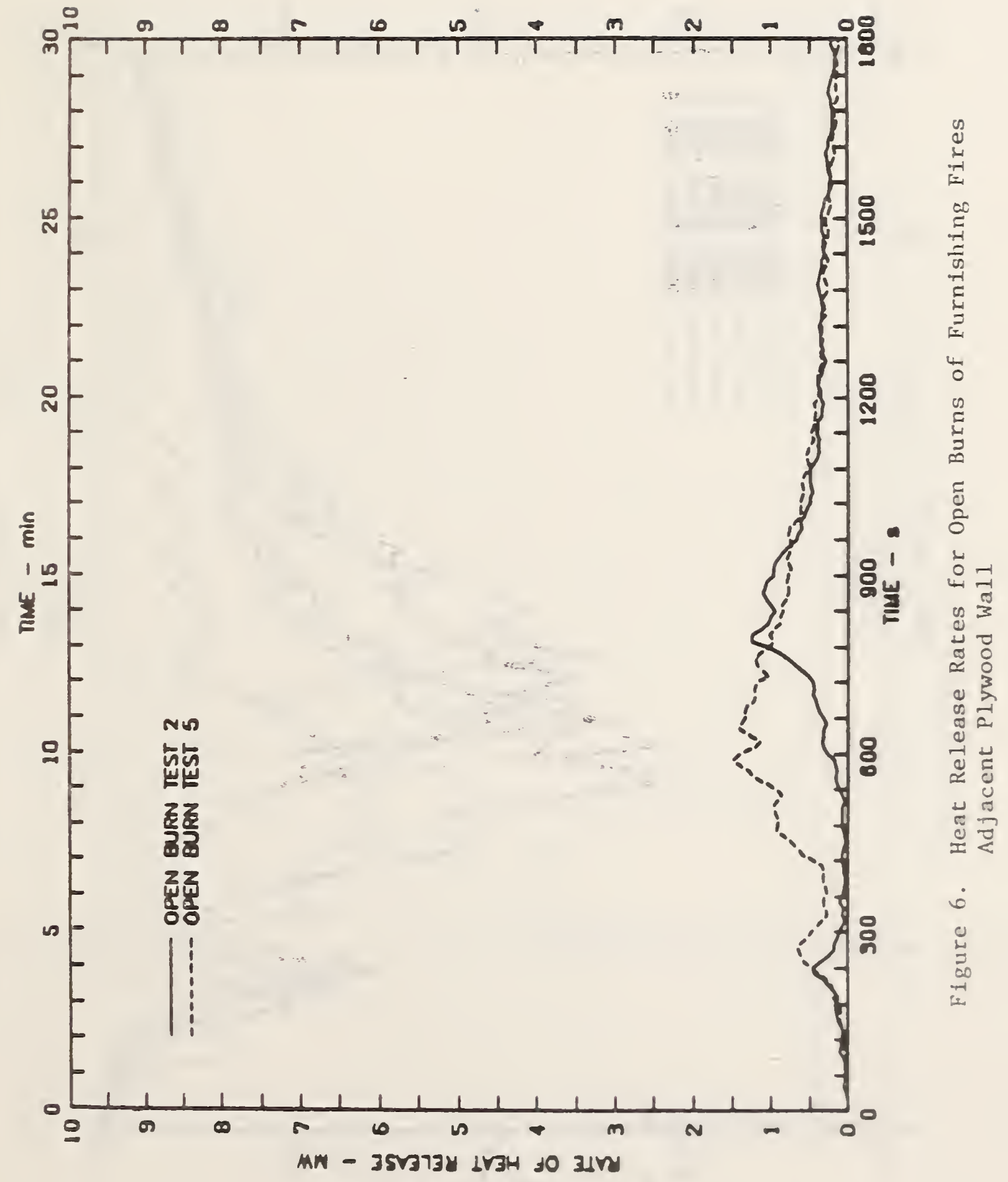




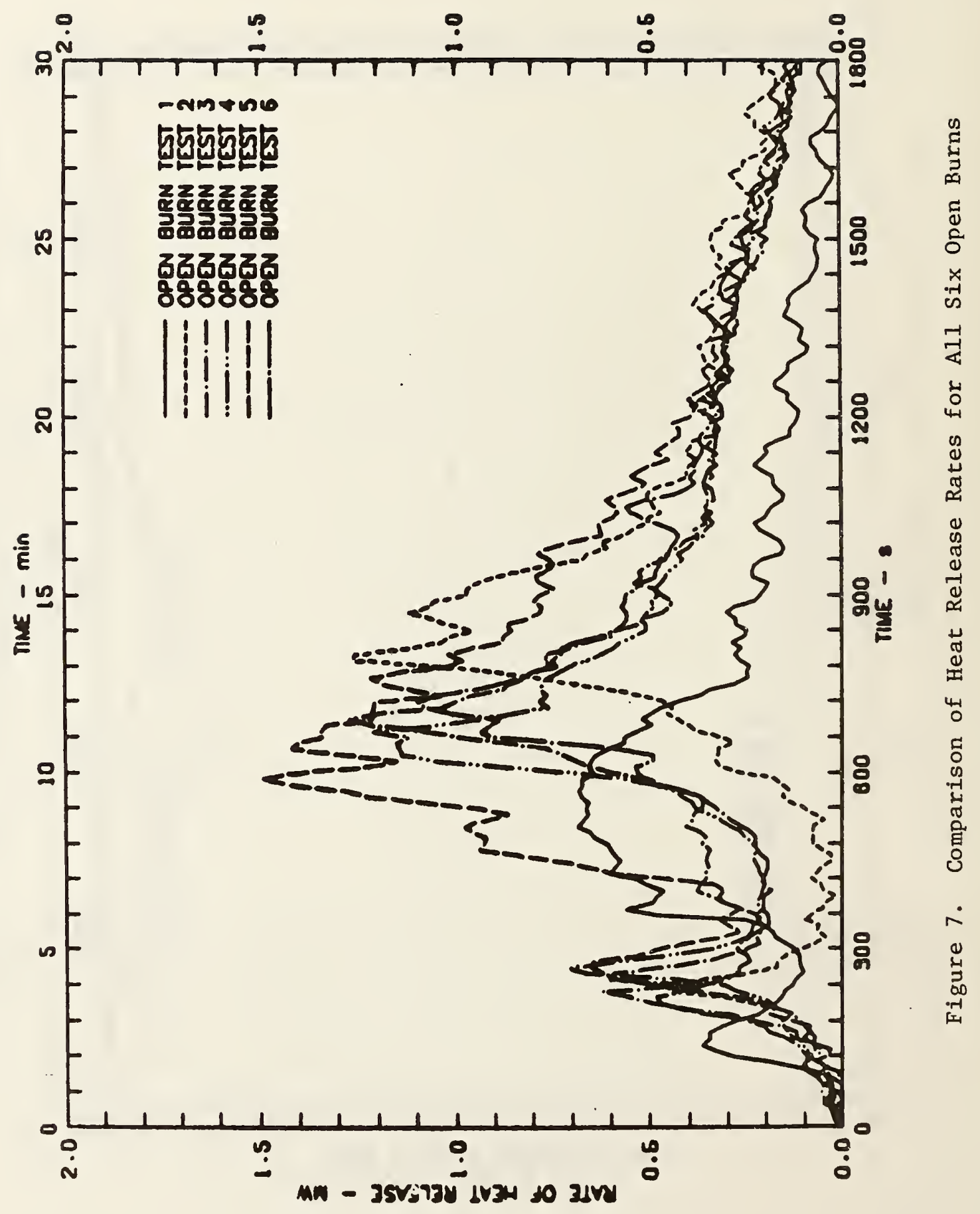




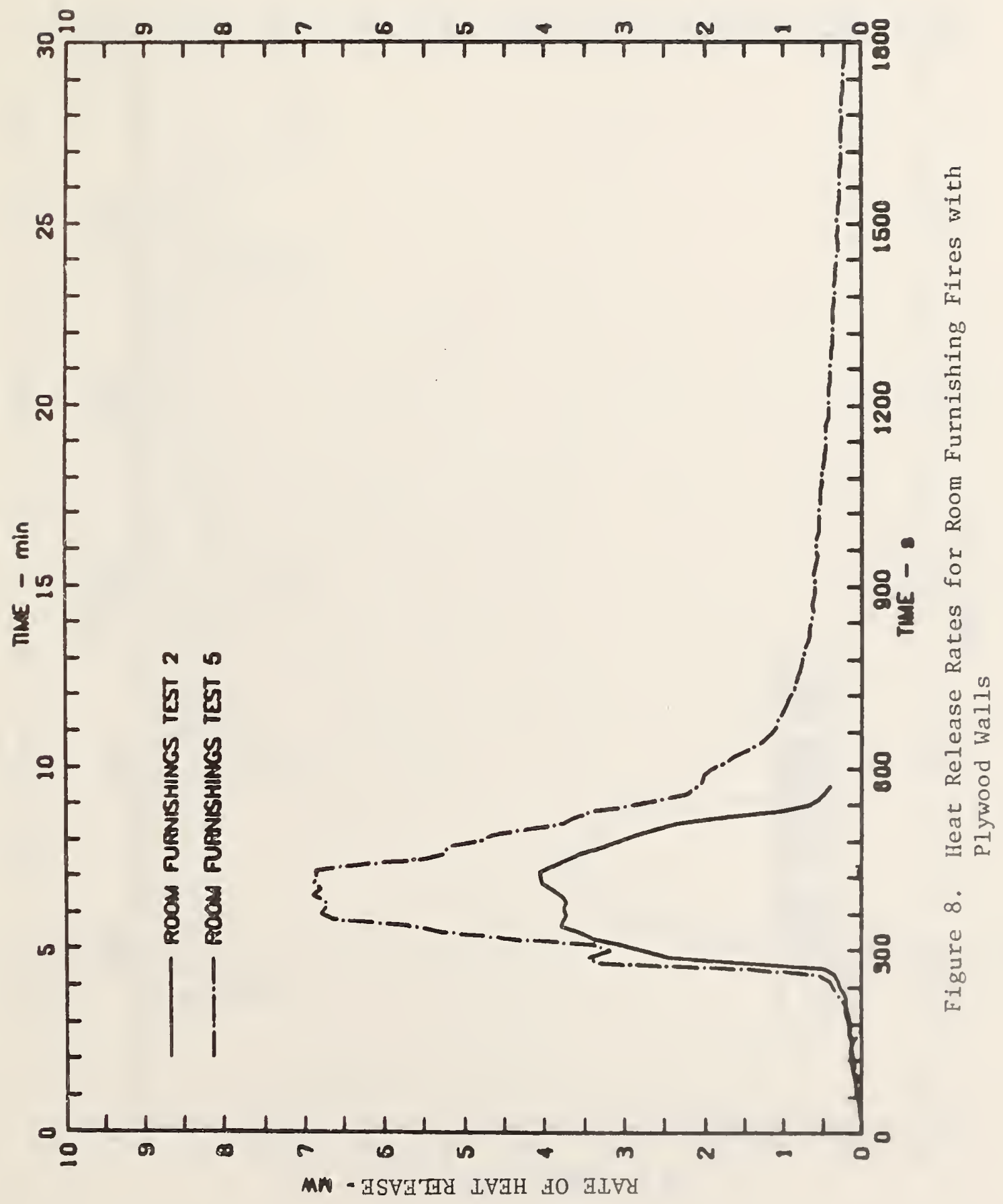




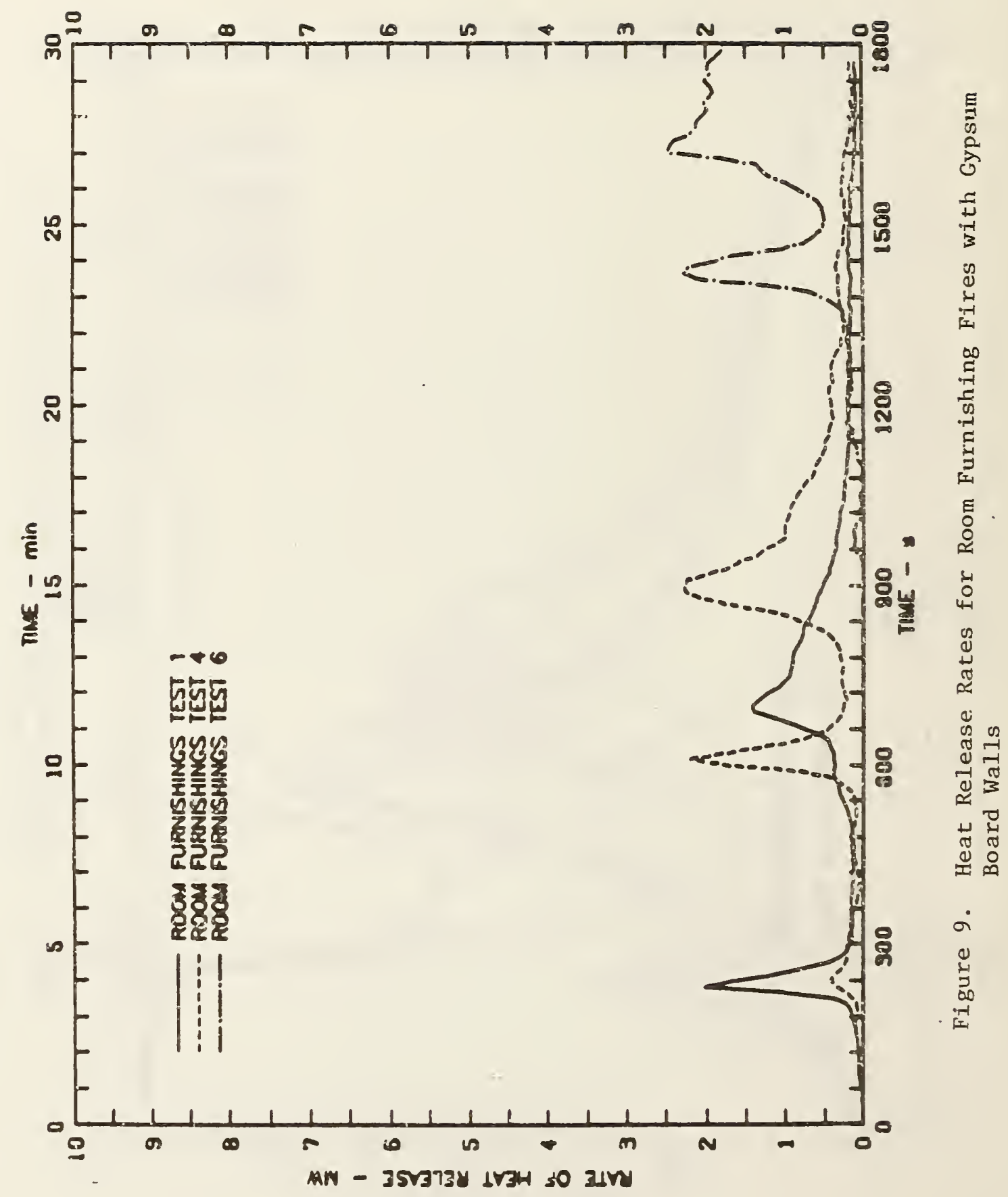




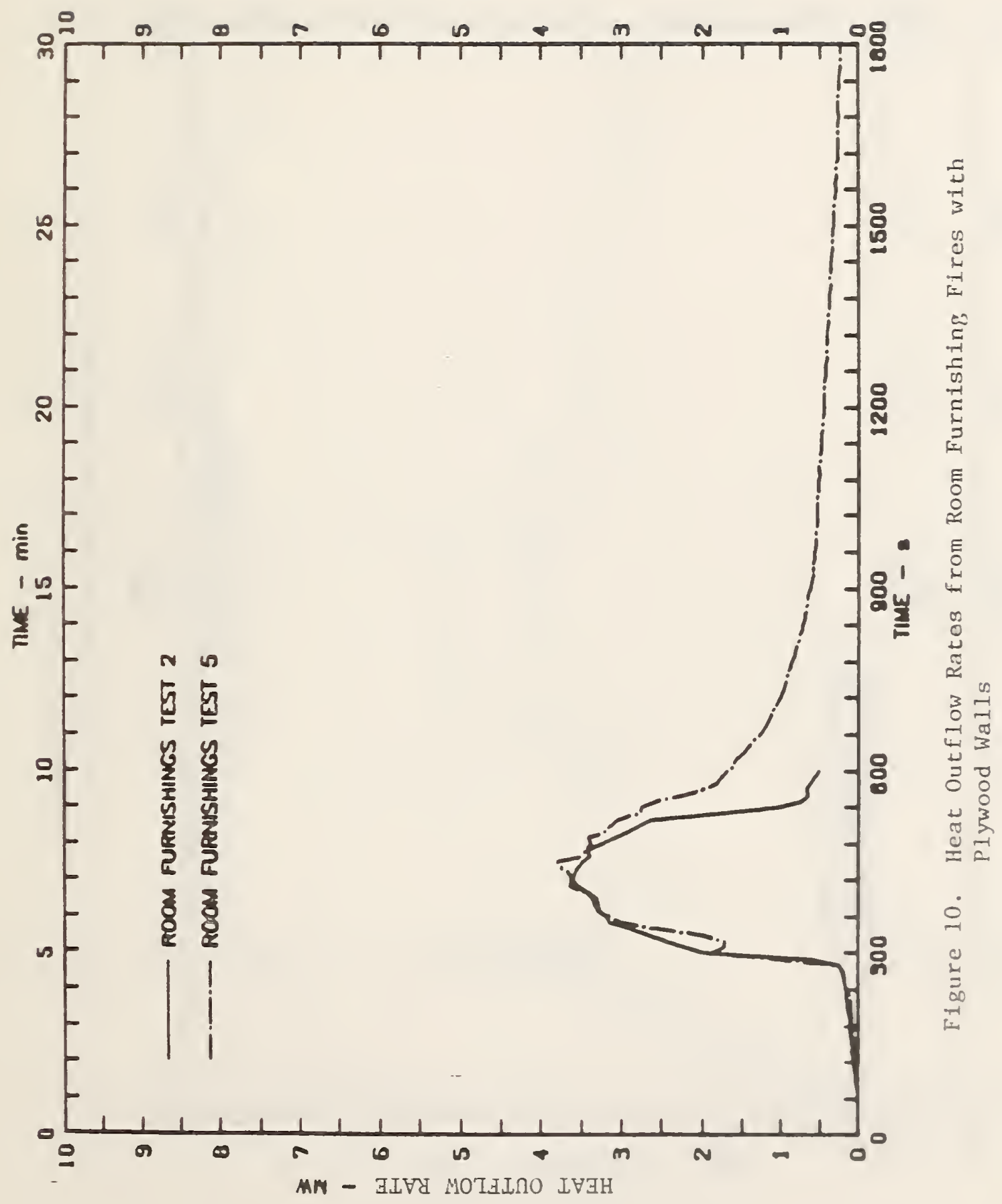




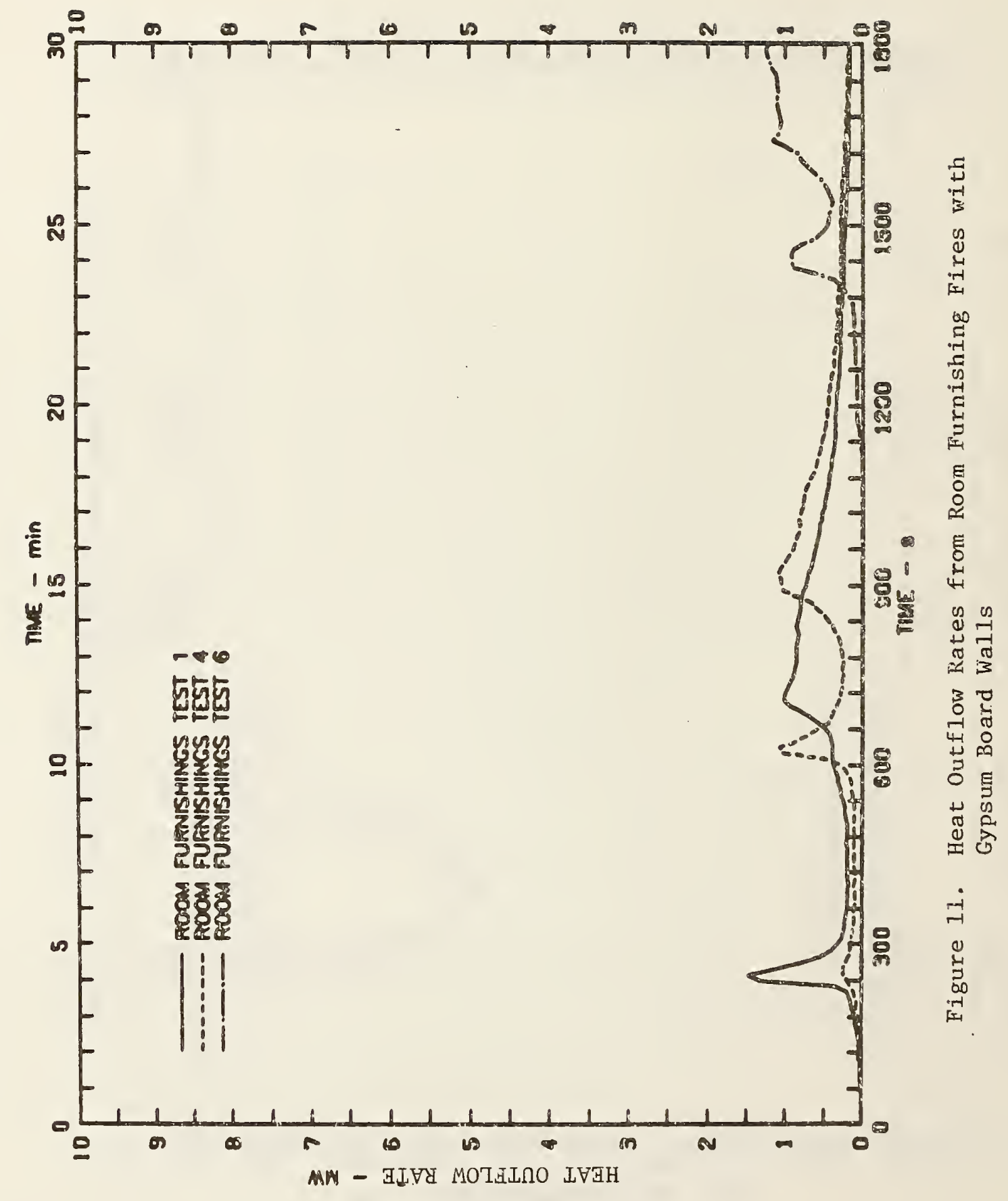




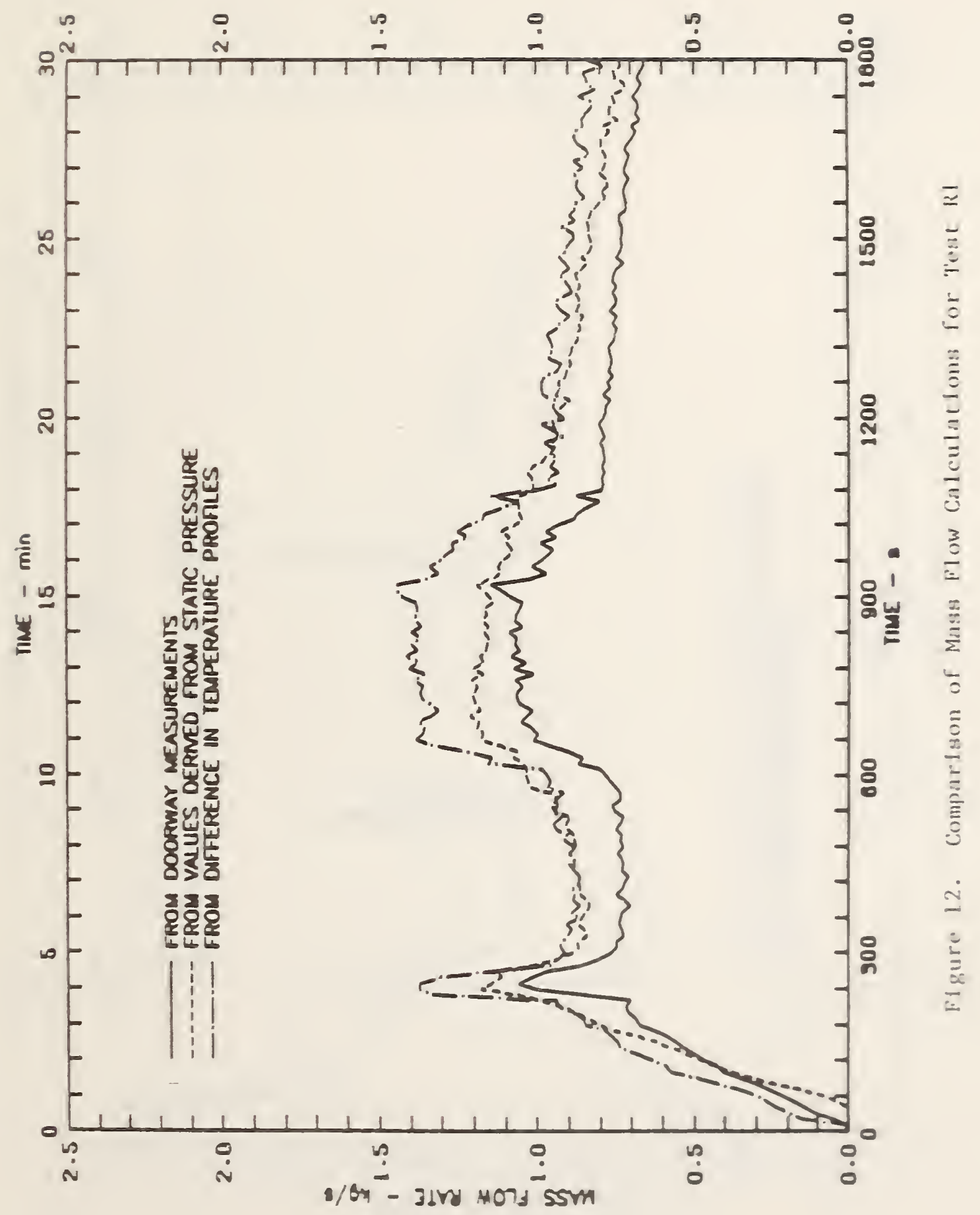




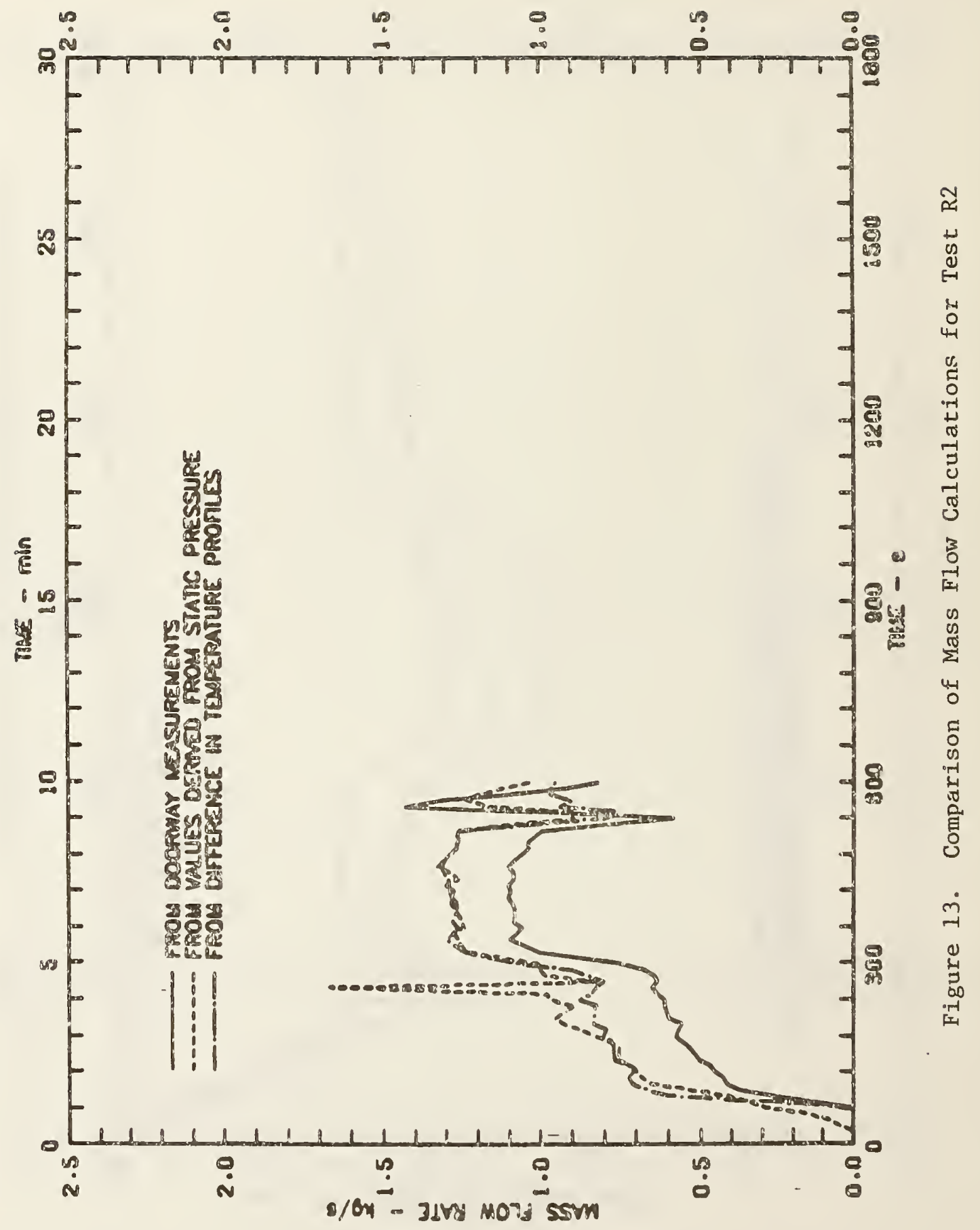




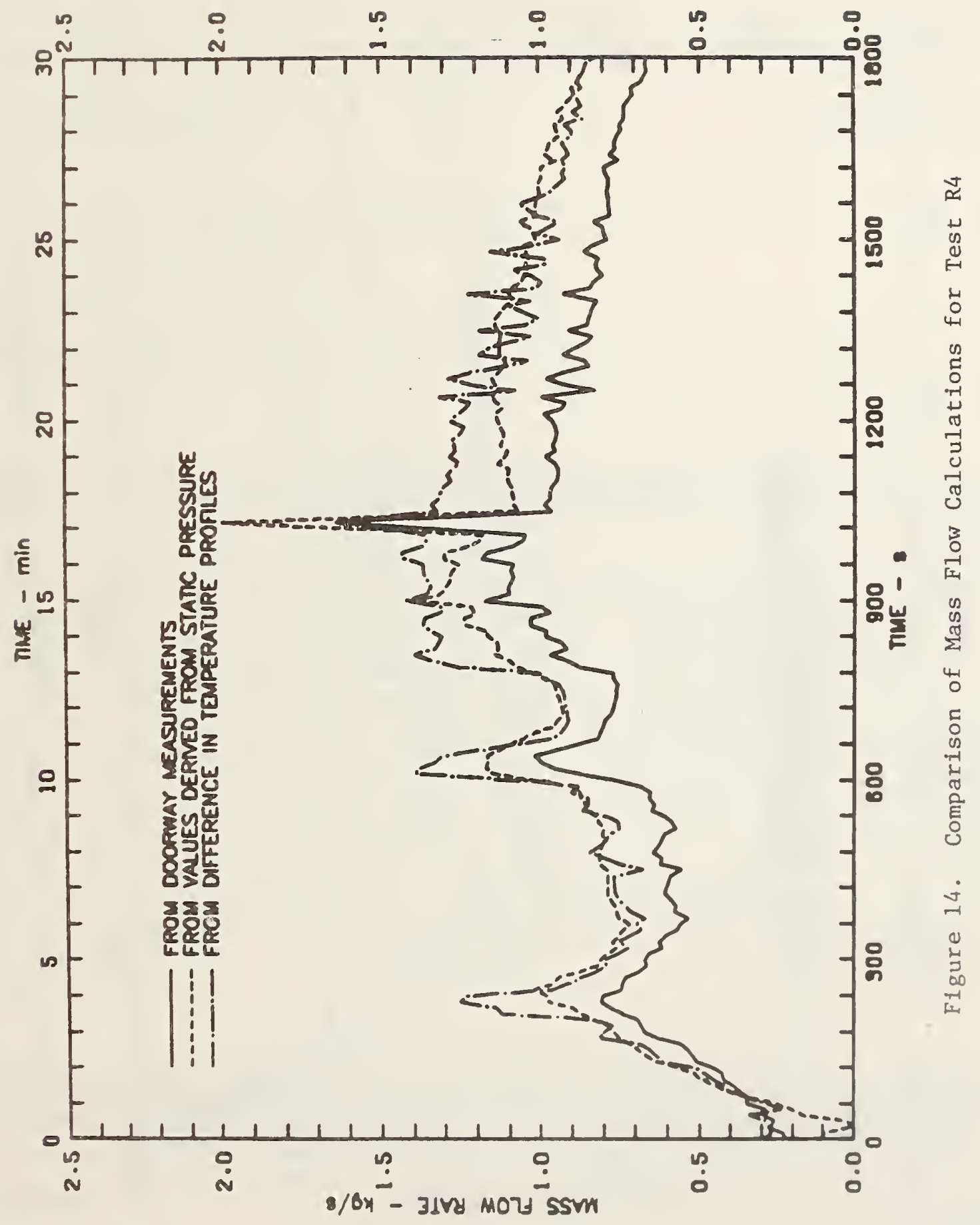




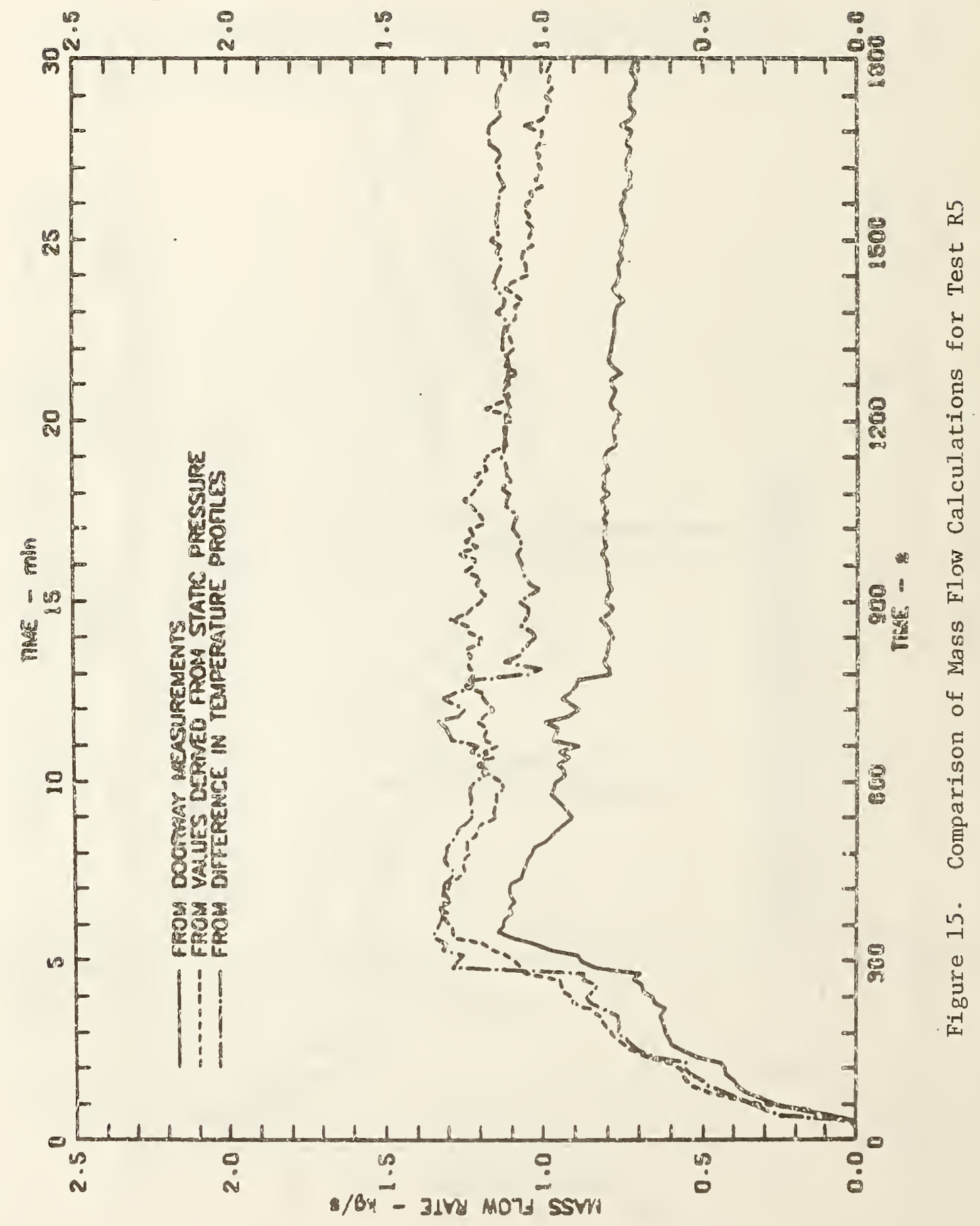


$A A=E V \cdot 2 \cdot R C$

LPT OF COMM

1. PUBLICATION OR

REPORT NO.

IBLIOGRAPHIC DATA

NBSIR $85-2998$

2. Performing Organ. Report No.

3. Publication Date

JHELT (See instructions)

4. TITLE AND SUBTITLE

EFFECT OF WALL AND ROOM SURFACES ON THE RATES OF HEAT, SMOKE

AND CARBON MONOXIDE PRODUCTION IN A PARK LODGING BEDROOM FIRE

February 1985

5. AUTHOR(S)

B. T. Lee

6. PERFORMING ORGANIZATION (If joint or other than NBS, see instructions)

7. ContracV Grant No.

NATIONAL BUREAU OF STANDARDS

DEPARTMENT OF COMMERCE

8. Type of Report \& Period Covered

WASHINGTON, D.C. 20234

9. SPONSORING ORGANIZATION NAME AND COMPLETE ADDRESS (Street, City, Stote, ZIP)

U.S. Park Service

U.S. Department of the Interior

Washington, D. C.

10. SUPPLEMENTARY NOTES

Document describes a computer program; SF-185, FIPS Software Summary, is attached.

11. ABSTRACT (A 200-word or less factual summary of most significant information. If document includes a significant bibliogrophy or literature survey, mention it here)

A furnishing arrangement representative of those in U.S. Park Service lodging facilities was evaluated for its open burn (free burn) characteristics. The arrangement consisted of a double bed with a wood headboard and one wood night table. The proximity of a wall and the effect of a room on the combustion of the same arrangement were examined. Wall finish materials were gypsum board and plywood. The presence or combustibility of an adjacent wall did not have a significant effect on the burning behavior of the furnishing arrangement. Nor did the effect of a room enclosure for the first few minutes subsequent to ignition. However, after this initial time interval, the effect of a room, lined with gypsum board finish, on the burning furn-. ishings was pronounced, with flashover occurring as early as $233 \mathrm{~s}$ with heat release rates of over $2 \mathrm{MW}$. This compared with a peak rate of $1.2 \mathrm{MW}$ for the open burn. Wood paneling in the room increased the peak rate to $7 \mathrm{MW}$. Mass flow of hot gases, smoke, and carbon monoxide from the room fires were measured. The use of a sprinkler or automatic door closing device activated by a smoke detector was shown to prevent room flashover.

12. KEY WORDS (Six to twelve entries; alphabetical order: capitalize only proper names; and separate key words by semicolons) beds (furniture); carbon monoxide; fire growth; flashover; fuel 1oad: furniture: heat releas: rate; interior finishes; room fires; smoke: smoke detectors. sprinkler syatema

13. AVAILABILITY

X] Unlimited

For Official Distribution. Do Not Release to NTIS

Order From Superintendent of Documents, U.S. Government Printing Office, Washington, D.C. 20402.

[X] Order From National Technical Information Service (NTIS), Springfield, VA. 2216I
14. NO. OF PRINTED PAGES

56

15. Price 


